\title{
Mechanistic insights into the tropo-inversion of the biphenyl moiety in chiral bis-amido phosphites and in their palladium(II) complexes
}

\author{
Alessandro Passera, ${ }^{\mathrm{a}, \mathrm{b}, \mathrm{c}}$ Anna Iuliano, ${ }^{\mathrm{b},{ }^{*}}$ Jesús J. Pérez-Torrente ${ }^{\mathrm{a}}$ and Vincenzo Passarelli, ${ }^{\mathrm{a}, \mathrm{d},{ }^{*}}$ \\ Chiral bis-amido phosphites L1 and L2 containing a diaminobiphenyl unit and a chiral alkoxy group derived \\ from either (-)-menthol or 3-acetoxy deoxycholic methyl ester have been synthesised. Both $\mathbf{L} 1$ and $\mathbf{L} 2$ react with \\ $\mathrm{PdCl}_{2}(\mathrm{NCPh})_{2}$ affording di- or mononuclear derivatives of formula trans- $[\mathrm{Pd}(\mu-\mathrm{Cl}) \mathrm{Cl}(\mathrm{L})]_{2}(\mathbf{1} \mathbf{a}, \mathrm{L}=\mathbf{L} \mathbf{1} ; \mathbf{1} \mathbf{b}, \mathbf{L}=\mathbf{L} \mathbf{2})$ or trans- \\ $\operatorname{PdCl}_{2}(\mathrm{~L})_{2}(\mathbf{2} \mathbf{a}, \mathrm{L}=\mathbf{L} \mathbf{1} ; \mathbf{2} \mathbf{b}, \mathrm{L}=\mathbf{L} \mathbf{2})$ depending on the Pd:L molar ratio. The crystal structure of $(M, P)-\mathbf{1 a}$ confirms the trans \\ arrangement of the ligands $\mathbf{L} \mathbf{1}$ and shows an unusual puckering of the $\mathrm{Pd}_{2}(\mu-\mathrm{Cl})_{2}$ core $\left(46^{\circ}\right)$. Both the ligands $\mathbf{L} \mathbf{1}$ and $\mathbf{L} \mathbf{2}$ \\ and its complexes $(\mathbf{1}, \mathbf{2})$ are fluxional in solution as a consequence of the tropo-inversion of the diaminobiphenyl unit. For \\ L1, L2, 1a and 2a a combined study including variable temperature ${ }^{31} \mathrm{P}\left\{{ }^{1} \mathrm{H}\right\} \mathrm{NMR}$ spectroscopy and line shape analysis, \\ Eyring plots and DFT calculations have shed light on the mechanism of the tropo-inversion.
}

\section{Introduction}

Metal complexes of chiral tropos, i.e. chirally flexible, ligands have proven to work as effective asymmetric catalysts in different enantioselective reactions ${ }^{1}$ and they result attractive since no resolution is required. In these complexes the conformational control of the tropos unit is obtained by the transfer of the chiral information from an enantiomer of a stereochemically stable ligand, through the coordination sphere of the metal centre, ${ }^{2}$ or by means of the chiral control exerted by an enantiopure moiety, possessing fixed stereogenic elements, covalently linked to the flexible unit. ${ }^{3}$ In both cases the conformational preference is allied to the effectiveness of the chiral stereochemically stable moiety to transfer the chiral information, but sometimes it can be triggered by the substrate of the reaction in the course of the catalytic cycle. ${ }^{4}$ In this last case the tropo-inversion phenomenon (interconversion of the two diastereomers) plays a crucial role, allowing a diastereomeric mixture to be converted in a single diastereomer of the tropos catalytic complex. Therefore, the study and the elucidation of the tropo-inversion mechanism is fundamental to the design of these ligands and their corresponding dynamic enantioselective catalysts.

anstituto de Síntesis Química y Catálisis Homogénea (ISQCH), CSIC-Universidad de Zaragoza, Departamento de Química Inorgánica, Pedro Cerbuna 12, 50009 Zaragoza, Spain, passarel@unizar.es

b. Dipartimento di Chimica e Chimica Industriale, Università di Pisa, Via Moruzzi 13, 56124 Pisa, Italy, anna.iuliano@unipi.it

Classe di Scienze Matematiche e Naturali, Scuola Normale Superiore di Pisa, Piazza de Cavalieri 7, 56126 Pisa, Italy.

d. Centro Universitario de la Defensa, Ctra. Huesca s/n, 50090 Zaragoza, Spain Electronic Supplementary Information (ESI) available: Kinetic constants, Eyring plots, ${ }^{31} \mathrm{P}\left\{{ }^{1} \mathrm{H}\right\}$ NMR spectra of $\mathbf{L} \mathbf{2}, \mathbf{1} \mathbf{b}$ and $\mathbf{2} \mathbf{b}$, atomic coordinates and views of the calculated structures.
So far this kind of study has been carried out on free ligands, existing as enantiomeric mixture, ${ }^{5}$ and on metal complexes of 2,2'-bis(diphenylphosphane)-1,1'-biphenyl. ${ }^{6}$ By contrast, to the best of our knowledge, the study of tropo-inversion on ligands asymmetrically activated by means of covalent bond(s) to a stereochemically stable subunit and on their metal complexes has received less attention. Indeed only a limited number of studies on the stereodynamic characteristics of phosphites and phosphepines $^{7}$ and their rhodium complexes ${ }^{8}$ has been reported so far. In addition, a computational study on the stereodynamic properties of tropos quaternary ammonium salts has also been reported. ${ }^{9}$

Following our longstanding interest in the design of tropos ligands and in the use of their metal complexes as chiral catalysts, we now focused on the chiral bis-amido phosphites $\mathbf{L 1}$ and $\mathbf{L 2}$ (Scheme 1), where the chiral stereochemically stable subunit is a derivative of natural compounds, namely (-)menthol and 3-acetoxy deoxycholic methyl ester. The presence of two $\mathrm{P}-\mathrm{N}$ bonds, which increase the electronic density on the phosphorus atom, makes bis-amido phosphites more appropriate than parent phosphites to prepare palladium complexes with applications to enantioselective $\mathrm{C}-\mathrm{C}$

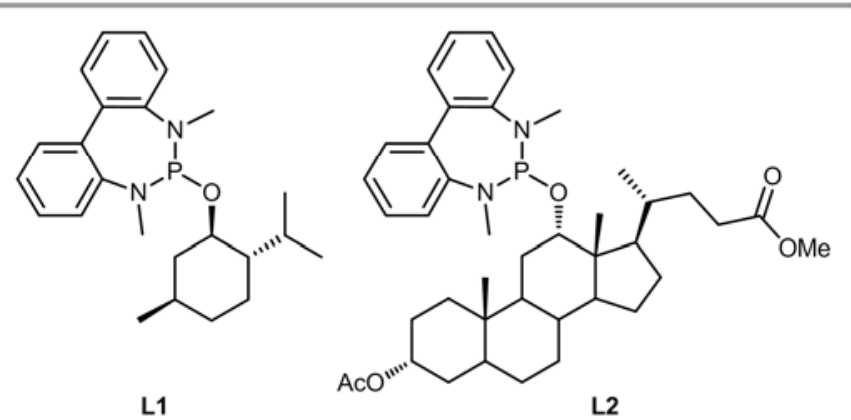

Scheme 1 
bond forming reactions. ${ }^{10}$ Although these properties make appealing the use of tropos bis-amido phosphites in palladiumbased asymmetric catalysis, no examples of palladium compounds with these ligands are reported in the literature and their tropo-inversion has not yet been explored. It is worth mentioning that this mechanistic information can be useful to understand the results of enantioselective catalysis as well as to design a chiral activator for complete control of the chirality. We present here a detailed study of the stereodynamic properties of bis-amido phosphites L1 and L2 and their palladium(II) complexes, by a combined approach based on NMR spectroscopy and DFT calculations, aimed at elucidating the tropo-inversion mechanism of both free and coordinated ligands.

\section{Results and Discussion}

Bis-amido phosphites. The chiral bis-amido phosphites $\mathbf{L} 1$ and L2 were prepared in good yields starting from $N, N^{\prime}$-dimethyl1,1'-diaminobiphenyl (C1), phosphorus trichloride, and a chiral enantiomerically pure alcohol, namely (-)-menthol $\left(\mathrm{R}^{1} \mathrm{OH}\right)$ and 3-acetoxy deoxycholic methyl ester $\left(\mathrm{R}^{2} \mathrm{OH}\right)$ (Scheme 2$)$.

Ligand L1 was obtained following the two-step route 1 in Scheme 2 going through: a) the preparation of the bis-amido chlorophosphite $\mathbf{C 2}$, and b) the reaction of $\mathbf{C 2}$ with (-)-menthol $\left(\mathrm{R}^{1} \mathrm{OH}\right)$. On the other hand the bulkier ligand $\mathbf{L} 2$ was obtained by reaction of $N, N^{\prime}$-dimethyl-1,1'-diaminobiphenyl (C1) and

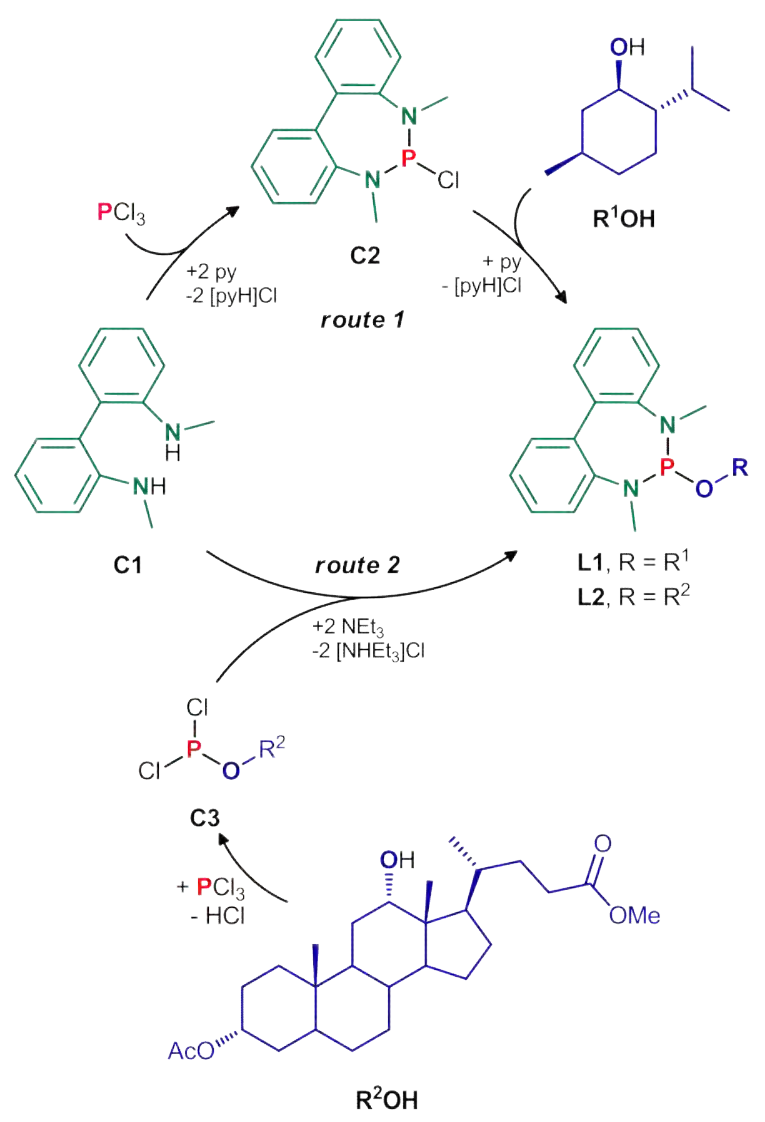

Table 1. Selected ${ }^{1} \mathrm{H},{ }^{13} \mathrm{C}$ and ${ }^{31} \mathrm{P}$ NMR data of $\mathbf{L} \mathbf{1}$ and $\mathbf{L} 2\left(\mathrm{C}_{6} \mathrm{D}_{6}, 298 \mathrm{~K}\right)$.

\begin{tabular}{lccccc} 
& & \multicolumn{2}{c}{$\boldsymbol{\delta}_{\mathrm{H}}\left({ }^{3} \boldsymbol{J}_{\mathrm{HP}}\right)$} & \multicolumn{2}{c}{$\boldsymbol{\delta}_{\mathrm{C}}\left({ }^{2} \boldsymbol{J}_{\mathrm{CP}}\right)$} \\
& $\boldsymbol{\delta}_{\mathrm{P}}$ & $\mathrm{NMe}$ & $\mathrm{POCH}$ & $\mathrm{NMe}$ & $\mathrm{POCH}$ \\
\hline L1 & \multirow{2}{*}{175.5} & $2.82(10.7)$ & $3.89(10.3)$ & $37.4(33.4)$ & $75.4(21.6)$ \\
& & $2.87(11.7)$ & & $38.1(38.5)$ & \\
\hline L2 & \multirow{2}{*}{164.9} & $2.83(12.0)$ & $4.32(6.2)$ & $37.6(34.1)$ & $77.5(12.1)$ \\
& & $2.90(11.8)$ & & $37.7(34.9)$ & \\
\hline
\end{tabular}

the dichlorophosphite $\mathrm{PCl}_{2}\left(\mathrm{OR}^{2}\right)$, resulting from the reaction of $\mathrm{PCl}_{3}$ and $\mathrm{R}^{2} \mathrm{OH}$ (Scheme 2, route 2 ). ${ }^{8 \mathrm{C}}$ It is noteworthy that uncharacterized byproducts and low yields were observed when $\mathrm{R}^{1} \mathrm{OH}$ was reacted with $\mathrm{PCl}_{3}$. Also, the reaction of $\mathbf{C 2}$ with $\mathrm{R}^{2} \mathrm{OH}$ was extremely slow and low yields of $\mathbf{L} \mathbf{2}$ were achieved even after $72 \mathrm{~h}$ of reaction, probably due to the high steric demand of $\mathrm{R}^{2} \mathrm{OH}$ and its consequent low nucleophilicity.

Selected NMR data for $\mathbf{L} \mathbf{1}$ and $\mathbf{L} \mathbf{2}$ are given in Table 1 . One ${ }^{31} \mathrm{P}$ resonance was observed for both $\mathbf{L 1}$ and $\mathbf{L 2}$ indicating that at room temperature a fast exchange should exist between the two diastereomers ${ }^{\S}$ (vide infra), one with the $M$ configuration and the other with the $P$ configuration of the biphenyl moiety (see ESI-Figure S1). Remarkably, both L1 and L2 contain two non-equivalent NMe groups (Table 1 ) as a result of the diastereotopic environment created by the chiral alkoxy substituents. Also, ${ }^{3} J_{\mathrm{HP}}$ and ${ }^{2} J_{\mathrm{CP}}$ coupling constants were observed in the ${ }^{1} \mathrm{H}$ and ${ }^{13} \mathrm{C}$ signals of the NMe and the $\mathrm{POCH}$ groups.

Variable temperature NMR measurements for both $\mathbf{L} 1$ and $\mathbf{L} 2$ showed that the tropo-inversion at the biphenyl moiety can be slowed down enough to observe the $(M)$ - and $(P)$ diastereomers. Figure 1 shows the ${ }^{31} \mathrm{P}\left\{{ }^{1} \mathrm{H}\right\}$ NMR spectra of $\mathbf{L} \mathbf{1}$ in the range $224-294 \mathrm{~K}$ (toluene- $d_{8}$ ). Interestingly, at $224 \mathrm{~K}$ three resonances could be reliably identified, namely one for one diastereomer (175.7 ppm, 67\%, either $M$ or $P$ ), and two overlapped for the other [179.23 (17\%); $179.21 \mathrm{ppm}(16 \%)$, Figure 1]. Upon rising the temperature up to $234 \mathrm{~K}$ the signals at 179.23 and $179.21 \mathrm{ppm}$ merge resulting in only one wellshaped resonance at $178.9 \mathrm{ppm}$. On these bases, these two resonances could be reasonably assigned to two exchanging conformers of one diastereomer of L1, tentatively those containing the substituents of the alkoxy moiety at axial and equatorial positions, ${ }^{11}$ respectively. Upon further rising the temperature the coalescence of the signals is observed between 274 and $284 \mathrm{~K}$. As for $\mathbf{L} 2$, at $188 \mathrm{~K}$ two ${ }^{31} \mathrm{P}$ resonances are observed at $165.2(52 \%)$ and 170.1 (48\%) ppm and the coalescence of the signals is achieved around $248 \mathrm{~K}$ (see ESIFigure S2). Both for $\mathbf{L} 1$ and $\mathbf{L 2}$, the line shape analysis ${ }^{12}$ of the ${ }^{31} \mathrm{P}\left\{{ }^{1} \mathrm{H}\right\}$ signals provided the kinetic constants for the equilibrium $(M)-\mathrm{L} \leftrightarrows(P)-\mathrm{L}$ (see ESI-Table S1) and the activation parameters were finally obtained by means of the Eyring plot (L1, $\Delta H^{\ddagger}=+14.6 \pm 0.3 ; \Delta S^{\ddagger}=+6.5 \pm 1.1 ; \Delta G_{298 \mathrm{~K}}^{\ddagger}=+12.7 \pm 0.6 \mathrm{kcal} \mathrm{mol}^{-1}$; L2, $\Delta H^{\ddagger}=+8.24 \pm 0.05 \mathrm{kcal} \mathrm{mol}^{-1} ; \Delta S^{\ddagger}=-10.4 \pm 0.2 \mathrm{cal} \mathrm{mol}^{-1} \mathrm{~K}^{-1}$; $\Delta G_{298 \mathrm{k}}^{\ddagger}=+11.3 \pm 0.1 \mathrm{kcal} \mathrm{mol}^{-1}$; see ESI-Figure S3). The calculated small activation enthalpies and the activation entropies close to zero nicely point at a non-dissociative 


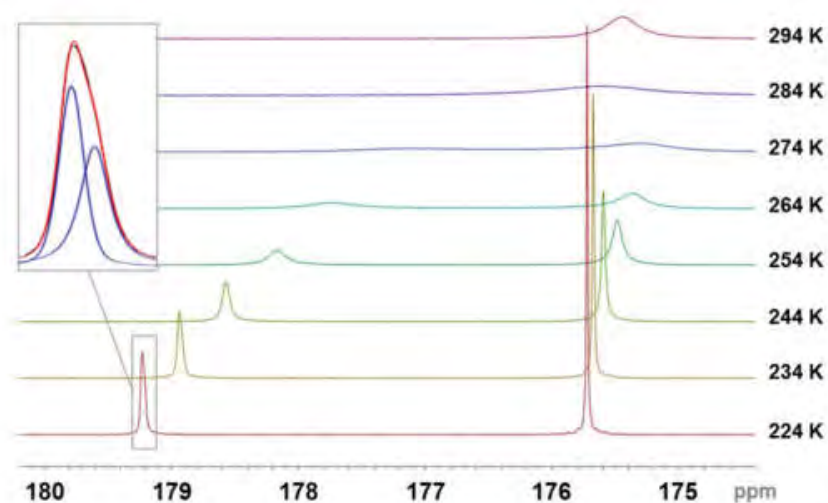

Figure 1. Vertically stacked ${ }^{31} \mathrm{P}\left\{{ }^{1} \mathrm{H}\right\}$ NMR spectra of $\mathbf{L} \mathbf{1}$ at different temperatures. The deconvolution analysis of the signal at $179.2 \mathrm{ppm}(224 \mathrm{~K})$ is shown in the inset. Data of the deconvolution analysis: $\delta_{\mathrm{p}} 179.23 \mathrm{ppm}, \Delta \mathrm{v}_{1 / 2} 4.1 \mathrm{~Hz}, 50.9 \%, \delta_{\mathrm{p}} 179.21 \mathrm{ppm}, \Delta \mathrm{v}_{1 / 2}$ $5.0 \mathrm{~Hz}, 49.1 \%$.

mechanism, reasonably ruling out any bond breaking in the course of the tropo-inversion of both $\mathbf{L} \mathbf{1}$ and $\mathbf{L} \mathbf{2}$.

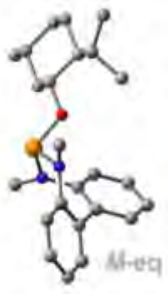

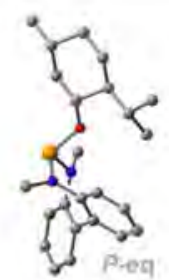

II

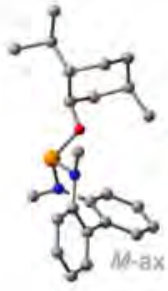

III

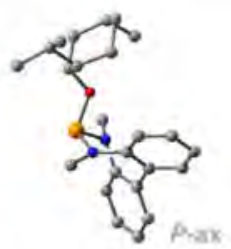

IV
(A)

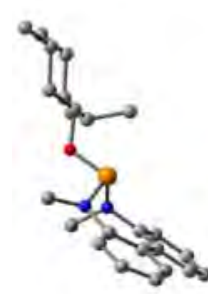

$t-T S \_I-I I$

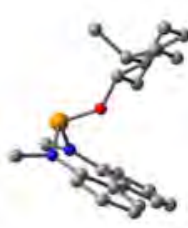

c-TS_|-||

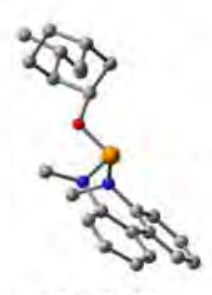

t-TS_III-IV

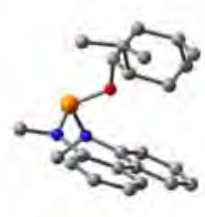

c-TS_III-IV
(B)

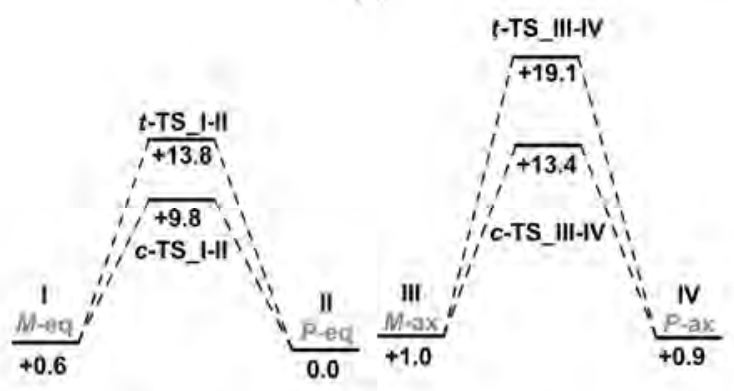

(C)

Figure 2. (A) Calculated structures of $\mathbf{L} \mathbf{1}$ with $M$ and $P$ configurations of the biphenyl unit and the axial (ax) and equatorial (eq) arrangements of the substituents of the alkoxy $\mathrm{C}_{6}$ ring. (B) Calculated structures of the transition states for the tropoinversion of the biphenyl moiety of $\mathbf{L}$. (C) Gibbs free energies profiles for the tropoinversion in L1 (298 K, toluene, $\left.\mathrm{kcal} \mathrm{mol}^{-1}\right)$.
In order to clarify the mechanism of the tropo-inversion of L1, DFT calculations were undertaken. The calculated structures of $(M)$-L1, $(P)$-L1 and of the transition states for the $(M)$-L1 $\leftrightarrows(P)$ L1 equilibrium are shown in Figure 2. In view of the NMR data (vide supra), both conformers, namely one with equatorial and the other with axial arrangements of the substituents of the alkoxy moiety, have been considered. Not surprisingly, the structures featuring the substituents at the equatorial positions are more stable than those with the substituents at the axial positions. ${ }^{11}$ Interestingly, the small energy difference between the two conformers nicely fit in with the presence of one axial conformer in solution at $224 \mathrm{~K}$, as suggested by the above mentioned NMR data.

Two non-equivalent transition state structures have been encountered for both the axial and the equatorial conformers. As a common characteristic, the calculated transition states feature a nearly flat biphenyl unit. Nevertheless, taking the plane containing the phosphorus and the nitrogen atoms as the reference, the structures of $\boldsymbol{t}$-TS_I-II and $\boldsymbol{t}$-TS_III-IV feature a trans arrangement of the oxygen atom with respect to the biphenyl moiety, while the structures of c-TS_I-II and c-TS_III-IV feature a cis arrangement. The flat biphenyl moiety reasonably results from the internal rotation around the carbon-carbon bond joining the two phenyl ring. Yet two independent molecular motions should be responsible for the above mentioned trans and cis arrangements. Taking the diastereomer II ( $P$-eq) as an example (Figure 3$)$, the phenyl ring of II labeled as $b$ is trans to the oxygen whereas that labeled as $a$ is cis. Thus, looking at the model molecule in Figure $3, \boldsymbol{t}$-TS is the result of turning the cis phenyl ring a clockwise around the $\mathrm{C}\left(\mathrm{sp}^{2}\right)-\mathrm{C}\left(\mathrm{sp}^{2}\right)$ bond, while $c$-TS results from turning the trans phenyl ring $b$ anticlockwise.

In view of the Gibbs free energy profile shown in Figure 2, despite the fact that fast equilibria between equatorial and axial conformers should occur in solution, ${ }^{11}$ the tropoinversion should take place preferentially via the transition state $c$-TS_I-II involving the equatorial conformer.

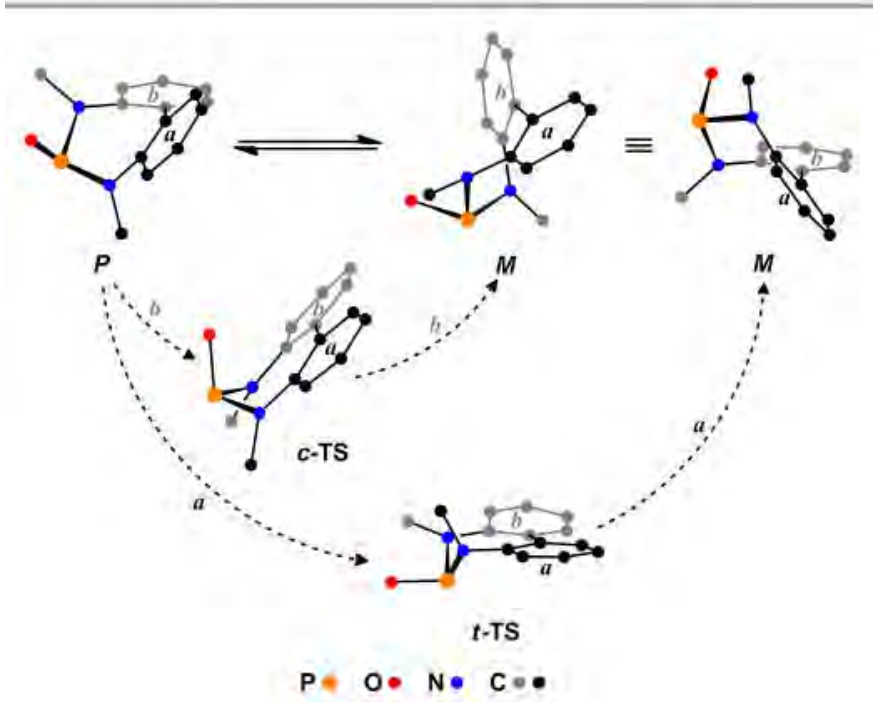

Figure 3. Sequences $P \rightarrow t$-TS $\rightarrow M$ and $P \rightarrow c$-TS $\rightarrow M$ leading to the tropo-inversion of L1. The substituent of the oxygen atom is omitted for clarity. 
In the case of L2 (see ESI-Figure S4), similarly to L1, two nonequivalent transition states were calculated for the tropoinversion $(M)-\mathbf{L 2} \leftrightarrows(P)-\mathbf{L} 2\left(\Delta G_{\mathrm{r}}=+1.8 \mathrm{kcal} \mathrm{mol}^{-1}\right)$, namely with either a cis $\left(\Delta G^{\ddagger} 298 \mathrm{~K}=+19.2 \mathrm{kcal} \mathrm{mol}^{-1}\right)$ or a trans $\left(\Delta G^{\ddagger}{ }_{298 \mathrm{~K}}=+12.2 \mathrm{kcal} \mathrm{mol}^{-1}\right)$ arrangement of the oxygen atom with respect to the flat biphenyl moiety. Thus, like for L1, the tropo-inversion should take place preferentially via the transition state with a cis arrangement of the oxygen atom and the inverting biphenyl moiety.

Synthesis of palladium(II) complexes. L1 and L2 react with $\mathrm{PdCl}_{2}(\mathrm{NCPh})_{2}$ affording high yields of the dinuclear complexes trans $-[\mathrm{Pd}(\mu-\mathrm{Cl}) \mathrm{Cl}(\mathrm{L})]_{2} \quad(\mathbf{1} \mathbf{a}, \quad \mathrm{L}=\mathbf{L} \mathbf{1} ; \mathbf{1} \mathbf{b}, \mathrm{L}=\mathbf{L} \mathbf{2})$ or the mononuclear complexes trans $-\mathrm{PdCl}_{2}(\mathrm{~L})_{2}(\mathbf{2 a}, \mathbf{L}=\mathbf{L} \mathbf{1} ; \mathbf{2} \mathbf{b}, \mathbf{L}=\mathbf{L 2})$ depending on the L:Pd molar ratio (Scheme 3 ). Interestingly, when the reaction of $\mathbf{L 1} / \mathbf{L} 2$ with $\mathrm{PdCl}_{2}(\mathrm{NCPh})_{2}$ in $1: 1$ molar ratio was monitored by ${ }^{31} \mathrm{P}$ NMR spectroscopy, the formation of $\mathbf{2} \mathbf{a} / \mathbf{2} \mathbf{b}$ was observed first, followed by the quantitative formation of $\mathbf{1 a / 1} \mathbf{b}$. Accordingly $\mathbf{1 a} / \mathbf{1} \mathbf{b}$ was almost quantitatively obtained when $\mathbf{2 a} \mathbf{2} \mathbf{b}$ was reacted with $\mathrm{PdCl}_{2}(\mathrm{NCPh})_{2}$ (1:1). Further, $\mathbf{1 a} / \mathbf{1} \mathbf{b}$ readily reacts with $\mathbf{L 1} / \mathbf{L} \mathbf{2}$ (1:2) affording $\mathbf{2 a / 2 b .}$

As a general remark, the proposed trans arrangement in $\mathbf{1 a} / \mathbf{1 b}$ and $\mathbf{2} \mathbf{a} / \mathbf{2} \mathbf{b}$ should be the consequence of the high steric demand of $\mathbf{L 1}$ and $\mathbf{L 2}$. Indeed, cis isomers of $\mathbf{1 a}$ and $\mathbf{2 a}$ were calculated to be less stable (vide infra) than the trans ones, and, as for L2, molecular models of the putative cis isomers of both $\mathbf{1 b}$ and $\mathbf{2 b}$ showed that parts of the ligands $\mathbf{L} \mathbf{2}$ would overlap.

${ }^{1} \mathrm{H}$ DOSY measurements were carried out at room temperature on solutions of $\mathbf{L} \mathbf{1}, \mathbf{L} \mathbf{2}$, and the corresponding complexes $\mathbf{1 a / 1} \mathbf{b}$ and $\mathbf{2 a} \mathbf{a} \mathbf{2} \mathbf{b}$ (Table 2 ). In each case all the diastereomers (vide infra) exhibit identical diffusion coefficients and the differences among the calculated hydrodynamic radii nicely fit in with the proposed structure of the complexes. Indeed the hydrodynamic radii of the metal complexes $\mathbf{1 a} / \mathbf{1} \mathbf{b}$ and $\mathbf{2 a / 2} \mathbf{b}$ are significantly bigger than that of the corresponding uncomplexed ligands. Further the mononuclear complexes $\mathbf{2 a}$ and $\mathbf{2} \mathbf{b}$ exhibit smaller hydrodynamic radii than the corresponding dinuclear derivatives $\mathbf{1 a}$ and $\mathbf{1} \mathbf{b}$, respectively.

Dinuclear palladium(II) complexes. ${ }^{\S}$ Single crystals of $(M, P)-\mathbf{1 a}$ were obtained by slow evaporation of a toluene solution of $\mathbf{1 a}$. Figure 4 shows the ORTEP view of the dinuclear complex and

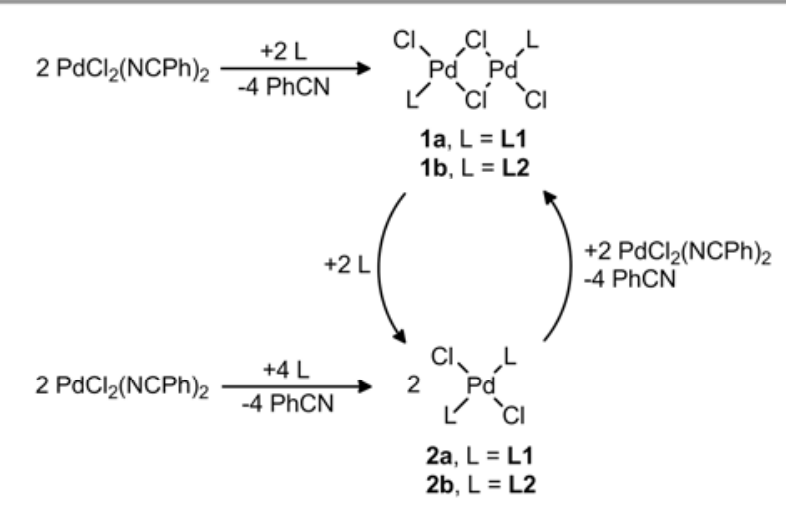

Scheme 3
Table 2. Selected ${ }^{1} \mathrm{H}$ DOSY data obtained on toluene solutions ( $\eta=0.56 \mathrm{mPa}$ s) at $298 \mathrm{~K}$ with an approximate concentration of $1.0 \cdot 10^{-2} \mathrm{M}$.

\begin{tabular}{ccc} 
Compound & $\boldsymbol{D} \cdot \mathbf{1 0}^{\mathbf{1 0}}\left(\mathbf{m}^{\mathbf{2}} \mathrm{s}^{-\mathbf{1}}\right)$ & $\boldsymbol{r}_{\mathrm{H}}{ }^{\mathrm{a}}(\AA)$ \\
\hline L1 & 8.18 & 4.4 \\
\hline 1a & 5.22 & 7.5 \\
\hline 2a & 5.46 & 7.1 \\
\hline L2 & 7.24 & 5.4 \\
\hline 1b & $3.75^{\mathrm{b}}$ & 10.4 \\
\hline 2b & 4.72 & 7.7 \\
\hline
\end{tabular}

${ }^{\text {a }}$ calculated from the Stokes-Einstein equation $D=k_{\mathrm{B}} T /\left(6 \pi \eta r_{\mathrm{H}}\right) ;{ }^{\mathrm{b}}$ benzene solution ( $\eta=0.60 \mathrm{mPa}$ s).

Table 3 contains selected bond lengths and angles.

The palladium centres of $(M, P)$-1a are joined by two bridging chlorine atoms and feature a slightly distorted square planar coordination with a trans arrangement of the $\mathbf{L} 1$ ligands on the $\mathrm{Pd}_{2}(\mu-\mathrm{Cl})_{2}$ core. Palladium-chlorine and palladium-phosphorus bond lengths along with the trans arrangement of the two phosphorus atoms are similar to those observed in related structures. ${ }^{13} \quad$ Nevertheless the observed puckered conformation of the $\mathrm{Pd}_{2}(\mu-\mathrm{Cl})_{2}$ core in $(M, P)-1 \mathrm{a}\left(\theta 46.7^{\circ}\right)$ is unusual. A survey of the CCDC database has shown that as for now only a few examples of complexes of general formula trans- $[\mathrm{Pd}(\mu-\mathrm{Cl}) \mathrm{Cl}(\mathrm{P} \text {-donor })]_{2}$ contain a puckered $\mathrm{Pd}_{2}(\mu-\mathrm{Cl})_{2}$ core $\left(\theta 34-69^{\circ}\right),{ }^{14}$ whereas the largely most common conformation is planar or almost planar. Interestingly the complex featuring the highest puckering angle $\left(\theta 68.8^{\circ}\right)$ contains a bidentate diphosphano ligand spanning the two trans positions of the bimetallic core. ${ }^{14 c}$ In addition, it should be noted that also the solid state structure of complexes of formula cis- $[\mathrm{Pd}(\mu-\mathrm{Cl}) \mathrm{Cl}(\mathrm{P}-$ donor) $]_{2}$ with bidentate phosphano ligands spanning the cis positions contains a puckered core $\left(\theta 58-64^{\circ}\right)$ as a consequence of the severe constraint imposed by the bidentante ligand. ${ }^{15} \mathrm{Pd}$...Pd distances in the range 2.91-3.34 $\AA$ have been reported for complexes $[\mathrm{Pd}(\mu-\mathrm{Cl}) \mathrm{Cl}(\mathrm{P} \text {-donor })]_{2}$ in association with the puckering, indicating that metal-metal interactions could eventually exist (palladium Van der Waals

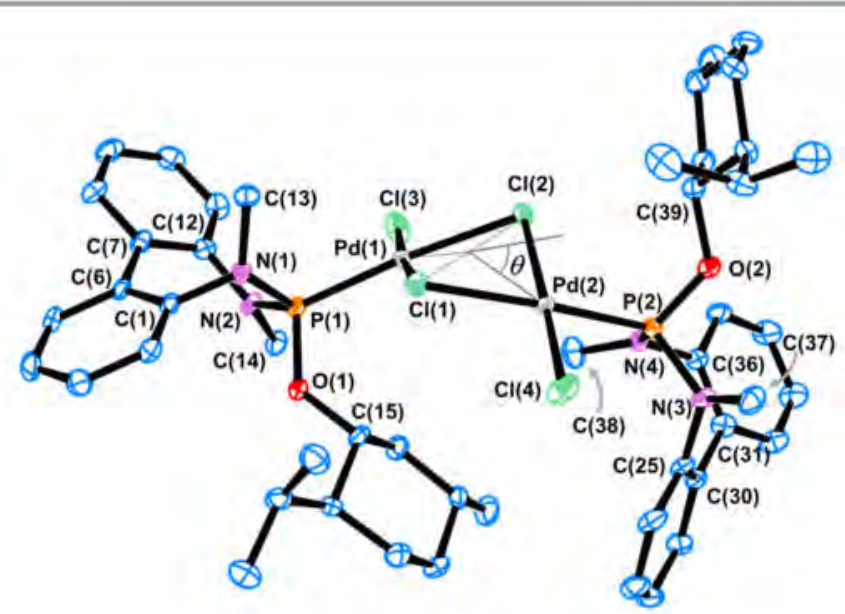

Figure 4. ORTEP view of $(\mathrm{M}, \mathrm{P})-[\mathrm{Pd}(\mu-\mathrm{Cl}) \mathrm{Cl}(\mathrm{L} 1)]_{2}(\mathbf{1 a})$ in $\mathbf{1 a} \cdot \mathrm{C}_{7} \mathrm{H}_{8}$ with the definition of the puckering angle $(\theta)$ of the $\mathrm{Pd}_{2}(\mu-\mathrm{Cl})_{2}$ moiety. Ellipsoids are at the $50 \%$ of probability and hydrogen atoms are omitted for clarity. 
Table 3. Selected bond lengths $(\AA ̊)$ and angles $\left({ }^{\circ}\right)$ for $[\mathrm{PdCl}(\mu-\mathrm{Cl})(\mathrm{L} 1)]_{2}(\mathbf{1 a})$ in $\mathbf{1 a} \cdot \mathrm{C}_{7} \mathrm{H}_{8}$.

$\begin{array}{ccc}C(1)-\mathrm{N}(1) 1.445(6) & \mathrm{N}(4)-\mathrm{P}(2) 1.646(4) & \mathrm{Cl}(2)-\mathrm{Pd}(2) 2.3277(13) \\ \mathrm{C}(12)-\mathrm{N}(2) 1.433(7) & \mathrm{O}(1)-\mathrm{P}(1) 1.572(4) & \mathrm{Cl}(2)-\mathrm{Pd}(1) 2.4373(13) \\ \mathrm{C}(25)-\mathrm{N}(3) 1.443(6) & \mathrm{O}(2)-\mathrm{P}(2) 1.574(4) & \mathrm{Cl}(3)-\mathrm{Pd}(1) 2.2763(14) \\ \mathrm{C}(36)-\mathrm{N}(4) 1.439(6) & \mathrm{P}(1)-\mathrm{Pd}(1) 2.2127(13) & \mathrm{Cl}(4)-\mathrm{Pd}(2) 2.2752(14) \\ \mathrm{N}(1)-\mathrm{P}(1) 1.645(4) & \mathrm{P}(2)-\mathrm{Pd}(2) 2.2155(14) & \mathrm{C}(6)-\mathrm{C}(7) 1.486(7) \\ \mathrm{N}(2)-\mathrm{P}(1) 1.662(4) & \mathrm{Cl}(1)-\mathrm{Pd}(1) 2.3246(13) & \mathrm{C}(30)-\mathrm{C}(31) 1.483(7) \\ \mathrm{N}(3)-\mathrm{P}(2) 1.658(4) & \mathrm{Cl}(1)-\mathrm{Pd}(2) 2.4650(13) & \mathrm{Pd}(1)-\mathrm{Pd}(2) 3.2526(5) \\ \mathrm{C}(1)-\mathrm{N}(1)-\mathrm{C}(13) 116.0(4) & \mathrm{O}(2)-\mathrm{P}(2)-\mathrm{N}(3) 98.0(2) \\ \mathrm{C}(1)-\mathrm{N}(1)-\mathrm{P}(1) 116.0(3) & \mathrm{N}(4)-\mathrm{P}(2)-\mathrm{N}(3) 102.5(2) \\ \mathrm{C}(13)-\mathrm{N}(1)-\mathrm{P}(1) 122.9(3) & \mathrm{O}(2)-\mathrm{P}(2)-\mathrm{Pd}(2) 112.42(15) \\ \mathrm{C}(12)-\mathrm{N}(2)-\mathrm{C}(14) 118.0(4) & \mathrm{N}(4)-\mathrm{P}(2)-\mathrm{Pd}(2) 109.09(16) \\ \mathrm{C}(12)-\mathrm{N}(2)-\mathrm{P}(1) 121.2(3) & \mathrm{N}(3)-\mathrm{P}(2)-\mathrm{Pd}(2) 122.67(16) \\ \mathrm{C}(14)-\mathrm{N}(2)-\mathrm{P}(1) 117.9(3) & \mathrm{Pd}(1)-\mathrm{Cl}(1)-\mathrm{Pd}(2) 85.49(4) \\ \mathrm{C}(25)-\mathrm{N}(3)-\mathrm{C}(37) 116.5(4) & \mathrm{Pd}(2)-\mathrm{Cl}(2)-\mathrm{Pd}(1) 86.06(4) \\ \mathrm{C}(25)-\mathrm{N}(3)-\mathrm{P}(2) 117.3(3) & \mathrm{P}(1)-\mathrm{Pd}(1)-\mathrm{Cl}(3) 93.62(5) \\ \mathrm{C}(37)-\mathrm{N}(3)-\mathrm{P}(2) 122.4(3) & \mathrm{P}(1)-\mathrm{Pd}(1)-\mathrm{Cl}(1) 91.74(5) \\ \mathrm{C}(36)-\mathrm{N}(4)-\mathrm{C}(38) 113.8(4) & \mathrm{Cl}(3)-\mathrm{Pd}(1)-\mathrm{Cl}(1) 174.32(5) \\ \mathrm{C}(36)-\mathrm{N}(4)-\mathrm{P}(2) 119.4(3) & \mathrm{P}(1)-\mathrm{Pd}(1)-\mathrm{Cl}(2) 174.55(5) \\ \mathrm{C}(38)-\mathrm{N}(4)-\mathrm{P}(2) 124.7(3) & \mathrm{Cl}(3)-\mathrm{Pd}(1)-\mathrm{Cl}(2) 90.10(5) \\ \mathrm{O}(1)-\mathrm{P}(1)-\mathrm{N}(1) 108.0(2) & \mathrm{Cl}(1)-\mathrm{Pd}(1)-\mathrm{Cl}(2) 84.69(5) \\ \mathrm{O}(1)-\mathrm{P}(1)-\mathrm{N}(2) 99.5(2) & \mathrm{P}(2)-\mathrm{Pd}(2)-\mathrm{Cl}(4) 92.50(5) \\ \mathrm{N}(1)-\mathrm{P}(1)-\mathrm{N}(2) 103.9(2) & \mathrm{P}(2)-\mathrm{Pd}(2)-\mathrm{Cl}(2) 92.84(5) \\ \mathrm{O}(1)-\mathrm{P}(1)-\mathrm{Pd}(1) 112.60(14) & \mathrm{Cl}(4)-\mathrm{Pd}(2)-\mathrm{Cl}(2) 172.54(6) \\ \mathrm{N}(1)-\mathrm{P}(1)-\mathrm{Pd}(1) 110.80(15) & \mathrm{P}(2)-\mathrm{Pd}(2)-\mathrm{Cl}(1) 172.51(5) \\ \mathrm{N}(2)-\mathrm{P}(1)-\mathrm{Pd}(1) 120.86(16) & \mathrm{Cl}(4)-\mathrm{Pd}(2)-\mathrm{Cl}(1) 91.29(5) \\ \mathrm{O}(2)-\mathrm{P}(2)-\mathrm{N}(4) 111.4(2) & \mathrm{Cl}(2)-\mathrm{Pd}(2)-\mathrm{Cl}(1) 84.01(5) \\ & \\ & \end{array}$

radius $1.63 \AA$ ). ${ }^{16}$ When dealing with the dinuclear complex $(M, P)$-1a the $\mathrm{Pd}$...Pd distance of 3.2526(5) A reasonably rules out any intermetallic interaction. ${ }^{17}$

The geometry of nitrogen atoms in $(M, P)$-1a are almost planar. Indeed the distance from each nitrogen atom to the least square plane containing the directly bonded atoms, namely methyl carbon, phenyl ipso carbon and phosphorus, is in the range $0.13-0.20 \AA$, and accordingly the sum of the bond angles slightly $\left(<4^{\circ}\right)$ deviate from $360^{\circ}$. Also, both the $\mathrm{N}-\mathrm{C}^{\mathrm{ipso}}$ bond lengths (av. $1.44 \AA$ ) and the observed dihedral angle between the aromatic $C_{6}$ ring and the least square plane containing nitrogen, methyl-carbon, phenyl ipso-carbon, and phosphorus $\left[N(1), 86.7^{\circ} ; N(2), 56.3^{\circ} ; N(3), 64.2^{\circ} ; N(4), 79.0^{\circ}\right]$ suggest a negligible delocalization of the lone pair of the nitrogen on the aromatic ring. Further, the observed phosphorus-nitrogen

Table 4. Selected ${ }^{1} \mathrm{H},{ }^{13} \mathrm{C}$ and ${ }^{31} \mathrm{P}$ NMR data of 1a (toluene- $d_{8}, 233 \mathrm{~K}$ ).

\begin{tabular}{cccccc}
\hline & & \multicolumn{2}{c}{$\delta_{\mathrm{H}}\left({ }^{3} J_{\mathrm{HP}}\right)$} & \multicolumn{2}{c}{$\delta_{\mathrm{C}}\left({ }^{2} J_{\mathrm{CP}}\right)$} \\
& $\delta_{\mathrm{P}}$ & $\mathrm{NMe}$ & $\mathbf{P O C H}$ & $\mathrm{NMe}$ & $\mathbf{P O C H}$ \\
\hline$(\boldsymbol{M}, \boldsymbol{M})^{\mathrm{i}}$ & 86.0 & $3.16(12.9)$ & $5.66(6.2)$ & $43.5(21.8)$ & 82.5 \\
& & $2.91(9.2)$ & & $39.7(7.3)$ & \\
\hline$(\boldsymbol{M}, \boldsymbol{P})$ & 86.4 & $3.09(11.8)$ & $5.76(9.5)$ & $42.9(20.0)$ & 82.6 \\
& $\left(\mathrm{P}^{1}\right)$ & $2.97(8.3)$ & & $43.1(22.0)$ & \\
& 88.6 & $3.15(12.0)$ & $5.73(9.2)$ & $39.9(6.9)$ & 81.7 \\
& $\left(\mathrm{P}^{2}\right)$ & $2.95(7.0)$ & & $40.8(3.5)$ & \\
\hline$(P, P)^{\mathrm{ii}}$ & 88.9 & $3.82(12.4)$ & $5.82(10.1)$ & $42.5(20.0)$ & 81.9 \\
& & $2.94(7.8)$ & & $40.9(5.9)$ & \\
\hline
\end{tabular}

i $\operatorname{or}(P, P) ;{ }^{i i}$ or $(M, M)$

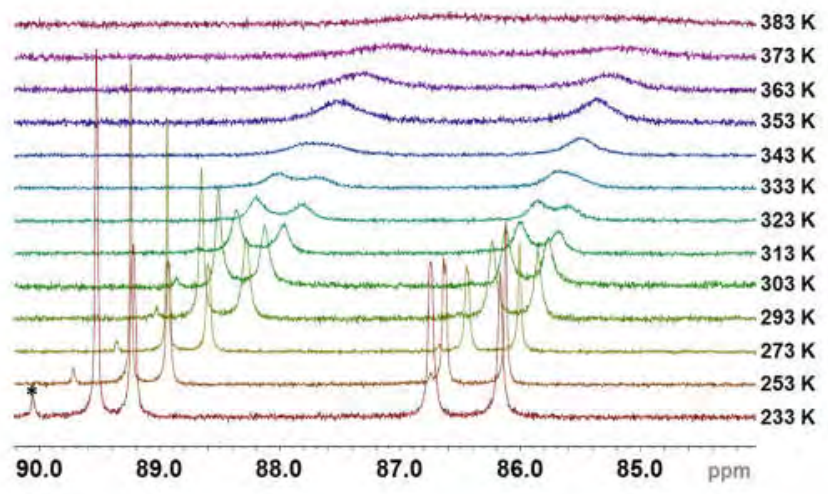

Figure 5. Vertically stacked ${ }^{31} \mathrm{P}\left\{{ }^{1} \mathrm{H}\right\}$ NMR spectra of $\mathbf{1 a}$ in toluene- $d_{8}$ at different temperatures. * unassigned.

bonds (av. $1.65 \AA$ ) are significantly shorter than phosphorusnitrogen single bonds (ca. $1.77 \AA$ ), thus pointing at that the P$\mathrm{N}$ bond should exhibit some degree of multiple bond. ${ }^{18}$

The ${ }^{31} \mathrm{P}\left\{{ }^{1} \mathrm{H}\right\}$ NMR spectrum of $1 \mathrm{a}$ in toluene- $d_{8}$ at $293 \mathrm{~K}$ (Figure 5 , Table 4) shows four resonances indicating the presence of three diastereomers, namely $(M, P)-1 \mathbf{a}\left(\delta_{\mathrm{p}} 86.2,88.3\right.$, ppm, total 50\%), $(M, M)$-1a and $(P, P)-1 \mathrm{a}\left(\delta_{\mathrm{P}} 85.9,20 \% ; 88.7 \mathrm{ppm}\right.$, $30 \%)$. Also the ${ }^{31} \mathrm{P}\left\{{ }^{1} \mathrm{H}\right\} \mathrm{NMR}$ signals are broad $\left(\Delta \mathrm{v}_{1 / 2}=10 \mathrm{~Hz}\right.$, av.) suggesting that the tropo-inversion is operative at room temperature. As a confirmation, upon rising the temperature up to $383 \mathrm{~K}$ the signals further broaden and their coalescence can be envisaged at about $383 \mathrm{~K}$ (Figure 5). More interestingly, on lowering the temperature, the line width diminishes and at $253 \mathrm{~K}$ the four bond phosphorus-phosphorus coupling constant of $(M, P)$-1a could eventually be observed $\left({ }^{4} J_{\mathrm{PP}}=3.0\right.$ $\mathrm{Hz}$ ).

Similarly to $\mathbf{L 1}$, each diastereomer of $\mathbf{1 a}$ contains two nonequivalent NMe groups per ligand, and as for the alkoxy moiety four partially overlapping non-equivalent $\mathrm{POCH}$ signals are observed (Table 4). Figure 6 shows selected regions of the ${ }^{1} \mathrm{H}$, the ${ }^{1} \mathrm{H}\left\{{ }^{31} \mathrm{P}\right\}$ and the ${ }^{1} \mathrm{H}^{31} \mathrm{P} \mathrm{HMBC}$ NMR spectra at $233 \mathrm{~K}$ with the proposed assignment. Further selected ${ }^{1} \mathrm{H}$ and ${ }^{13} \mathrm{C} N M R$ data are given in Table 4.

The solution behaviour of $\mathbf{1 b}$ is similar to that of $\mathbf{1 a}$. Indeed at $273 \mathrm{~K}$ the ${ }^{31} \mathrm{P}\left\{{ }^{1} \mathrm{H}\right\}$ NMR spectrum of $\mathbf{1 b}$ contains four signals suggesting the existence of three diastereomers namely $(M, M)$-1b, $(P, P)-\mathbf{1 b}$ (86.4 ppm 31\%, $86.3 \mathrm{ppm}, 37 \%)$ and $(M, P)-1 b(86.2,84.9$, total $32 \%)$. Also, the line width at $273 \mathrm{~K}$ $\left(20 \mathrm{~Hz}\right.$, av.) and the unique broad ${ }^{31} \mathrm{P}\left\{{ }^{1} \mathrm{H}\right\}$ NMR resonance at $85.0 \mathrm{ppm}$ at $366 \mathrm{~K}\left(\Delta \mathrm{v}_{1 / 2}=70 \mathrm{~Hz}\right)$ confirm that the tropoinversions $(M, M)-\mathbf{1} \mathbf{b} \leftrightarrows(M, P)-\mathbf{1 b}$ and $(M, P)-\mathbf{1} \mathbf{b} \leftrightarrows(P, P)-\mathbf{1} \mathbf{b}$ are operative (see ESI-Figure S2).

In order to gain insights into the solution behaviour of $1 \mathrm{a}$, the line shape analysis ${ }^{12}$ of its ${ }^{31} \mathrm{P}\left\{{ }^{1} \mathrm{H}\right\}$ NMR spectra was undertaken. Two kinetic constants, namely one for the equilibrium $(M, M)-\mathbf{1 a} \leftrightarrows(M, P)-\mathbf{1 a}$ and another for the equilibrium $(M, P)-\mathbf{1} \mathbf{a} \leftrightarrows(P, P)$-1a, were used in the course of the line shape analysis ${ }^{12}$ (see ESI-Table S2). As a result, the activation parameters obtained from the Eyring plots for the two processes (i: $\Delta H^{\ddagger}=+10.12 \pm 0.05 \mathrm{kcal} \mathrm{mol}^{-1} ; \Delta S^{\ddagger}=-19.9 \pm 0.1$ cal mol ${ }^{-1} \mathrm{~K}^{-1} ; \Delta G^{\ddagger}{ }_{298 \mathrm{~K}}=+16.1 \pm 0.1 \mathrm{kcal} \mathrm{mol}^{-1} ;$ ii: $\Delta H^{\ddagger}=+8.23 \pm 0.04$ $\mathrm{kcal} \mathrm{mol}{ }^{-1} ; \quad \Delta S^{\ddagger}=-23.9 \pm 0.1 \quad \mathrm{cal} \mathrm{mol}^{-1} \mathrm{~K}^{-1} ; \quad \Delta G^{\ddagger}{ }_{298 \mathrm{~K}}=+15.4 \pm 0.1$ 


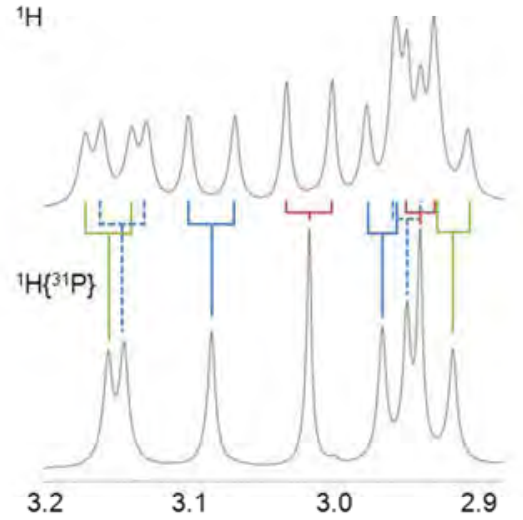

(A)

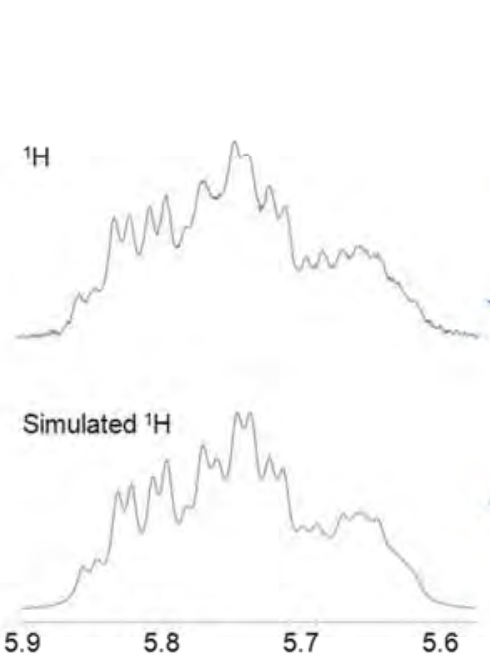

(B)

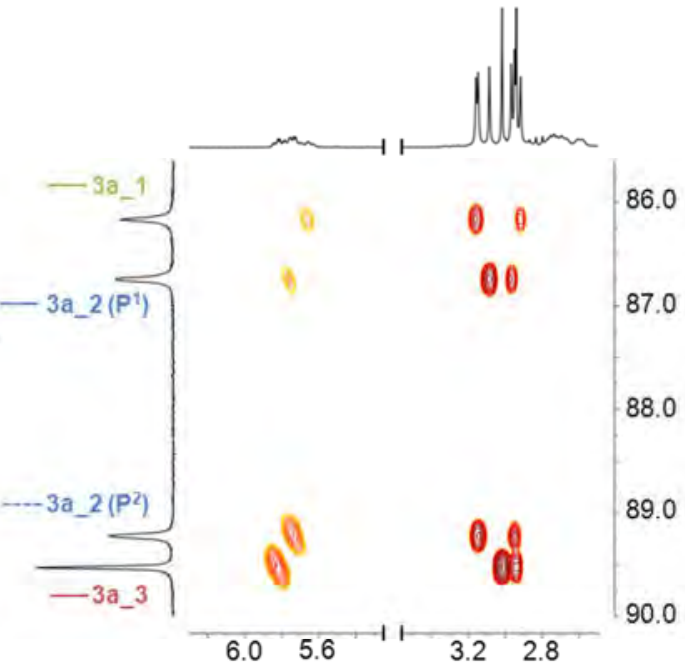

(C)

Figure 6. (A) Selected regions of the ${ }^{1} \mathrm{H}$ and ${ }^{1} \mathrm{H}\left\{{ }^{31} \mathrm{P}\right\}$ NMR spectra of $1 \mathrm{a}\left(233 \mathrm{~K}\right.$, toluene- $d_{8}$ ) showing the signals of the NMe groups; (B) selected region of the ${ }^{1} \mathrm{H}$ NMR spectrum of 1a $\left(233 \mathrm{~K}\right.$, toluene- $\left.d_{8}\right)$ showing the signals of the POCH groups along with the simulated spectrum; (C) selected regions of the ${ }^{1} \mathrm{H}^{31} \mathrm{P} H M B C$ NMR spectrum $\left(233 \mathrm{~K}\right.$, toluene- $\left.d_{8}\right)$. Data of the simulated ${ }^{1} \mathrm{H}$ NMR spectrum (400 MHz) of the POCH signals (B) are: $5.82\left(\mathrm{tdd},{ }^{3} \mathrm{~J}_{\mathrm{HH}}=10.2,{ }^{3} \mathrm{~J}_{\mathrm{HP}}=10.1,{ }^{3} \mathrm{~J}_{\mathrm{HH}}=4.2\right) ; 5.76\left(\mathrm{tdd},{ }^{3} \mathrm{JHH}_{\mathrm{HH}}=9.6,{ }^{3} \mathrm{JP}_{\mathrm{HP}}=9.5,{ }^{3} \mathrm{~J}_{\mathrm{HH}}=4.2\right) ; 5.73\left(\mathrm{tdd},{ }^{3} \mathrm{~J}_{\mathrm{HH}}\right.$ $\left.=9.2,{ }^{3} J_{\mathrm{HP}}=9.2,{ }^{3} \mathrm{~J}_{\mathrm{HH}}=4.2\right) ; 5.66\left(\mathrm{tdd},{ }^{3} J_{\mathrm{HH}}=10.8,{ }^{3} \mathrm{~J}_{\mathrm{HP}}=6.2,{ }^{3} \mathrm{~J}_{\mathrm{HH}}=3.7\right)$.

$\mathrm{kcal} \mathrm{mol}^{-1}$; see ESI-Figure S4) clearly indicate that similar to L1 a non-dissociative pathway for the tropo-inversion of coordinated $\mathbf{L} \mathbf{1}$ should be operative.

It is worth a mention that the Gibbs free energy barriers of the two tropo-inversions of coordinated L1 in 1a are similar (cf. $\Delta \mathrm{G}^{\ddagger}{ }_{298 \mathrm{~K}}$ as an example) indicating that the inversion of one ligand is scarcely affected by the configuration of the noninverting ligand. In addition the activation barrier of the coordinated ligand is higher than that of the free ligand, probably as a consequence of the steric congestion around the

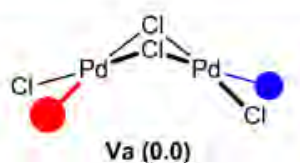

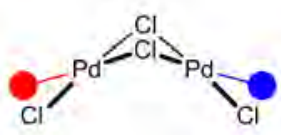

Vla $(+7.9)$

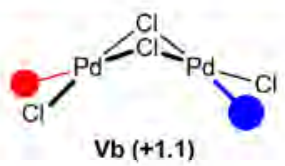

$\mathrm{Vb}(+1.1)$

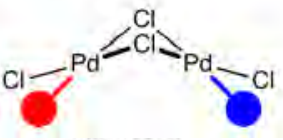

$\mathrm{Vlb}(+8.1)$
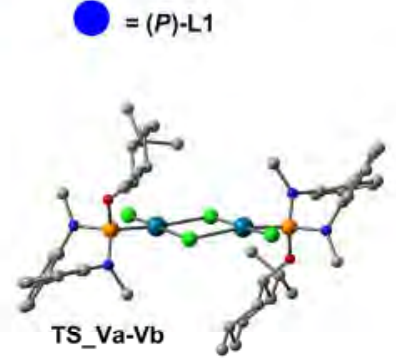

Figure 7. (top) Trans- $(\mathbf{V a}, \mathbf{V b})$ and cis-isomers (Vla, Vlb) of the diastereomer $(M, P)$ $[\mathrm{PdCl}(\mu-\mathrm{Cl})(\mathrm{L} 1)]_{2}$ of $1 \mathrm{a}$ along with their relative Gibbs free energies. (bottom) Gibbs free energy profile of the $\mathbf{V a} \leftrightarrows \mathbf{V b}$ intercoversion and calculated structure of its transition state (TS_Va-Vb). Gibbs free energies are in $\mathrm{kcal} \mathrm{mol}^{-1}$. metal center. DFT calculations were carried out in order to shed light on the structure of the diastereomers of $\mathbf{1 a}$ and eventually on its fluxional behaviour in solution. The relative stability of the four isomers $\mathbf{V a}, \mathbf{V b}, \mathbf{V l a}$, and $\mathbf{V I b}$ of formula $(M, P)-[\mathrm{Pd}(\mu-\mathrm{Cl}) \mathrm{Cl}(\mathrm{L1})]_{2}$ was first addressed (Figure 7, calculated structures are shown in ESI). It should be noted that $\mathbf{V a / V b}$ and $\mathrm{Vla} / \mathrm{VIb}$ are genuine pairs of isomers. Indeed, as a consequence of the puckering of $\mathrm{Pd}_{2}(\mu-\mathrm{Cl})_{2}$ in $\mathrm{Va} / \mathrm{Vb}$, the trans $-[\mathrm{Pd}(\mu-\mathrm{Cl}) \mathrm{Cl}(\mathrm{P})]_{2}$ backbone is chiral. On the other hand, the puckered structure cis- $[\mathrm{Pd}(\mu-\mathrm{Cl}) \mathrm{Cl}(\mathrm{P}-\text { donor })]_{2}$ is achiral, nevertheless the presence of two different $\mathrm{P}$-donor diastereomers, namely $(M)$-L1 and $(P)$-L1, makes the structures Vla and VIb pseudoasymmetric. The trans isomers $\mathbf{V a}$ and $\mathbf{~ V b}$ are significantly more stable than the cis isomers Vla and VIb thus confirming that the trans arrangement of two L1 ligands on the $\mathrm{Pd}_{2}(\mu-\mathrm{Cl})_{2}$ core should be preferred over the cis one. In addition, $\mathbf{V a}$ is virtually superimposable to the solid state structure of $(M, P)$-1a and accordingly it is more stable than the trans isomer $\mathbf{V b}$. As far as the solution behaviour is concerned, $\mathbf{V a}$ and $\mathbf{~ V b}$ should interconvert by means of a non-dissociative mechanism resembling the flapping of cyclobutane. ${ }^{19}$ Indeed the transition state $\mathbf{T S} \mathbf{V} \mathbf{V} \mathbf{a}-\mathbf{V b}$ for $\mathbf{V a} \leftrightarrows \mathbf{V b}$ features an almost planar $\mathrm{Pd}_{2}(\mu-\mathrm{Cl})_{2}$ core (Figure 7) and the calculated barrier $\left(+6.9 \mathrm{kcal} \mathrm{mol}^{-1}\right)$ is low enough to be easily overcome all over the range of temperature explored in the NMR measurements, thus preventing the direct observation of $\mathbf{V a}$ and $\mathbf{V b}$ in solution.

Similarly to trans- $(M, P)-[\mathrm{PdCl}(\mu-\mathrm{Cl})(\mathbf{L 1})]_{2}$, two pairs of isomers exist also for the diastereomers trans- $(M, M)-[\mathrm{PdCl}(\mu-\mathrm{Cl})(\mathbf{L 1})]_{2}$ and trans- $(P, P)-\mathrm{PdCl}(\mu-\mathrm{Cl})(\mathbf{L 1})]_{2}$, namely $\mathrm{VIla} / \mathrm{VIIb}$ and VIIIa/VIIIb, respectively (Figure 8 , calculated structures are shown in ESI). Further, like for $\mathbf{V a}$ and $\mathbf{V b}$, the equilibria VIla $\leftrightarrows$ VIIb and VIIla $\leftrightarrows$ VIIIb feature easily affordable barriers $\left(<+8 \mathrm{kcal} \mathrm{mol}^{-1}\right.$, Figure 8$)$ and the corresponding transition 


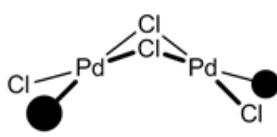

VIla $(M, M)$ VIIla $(P, P)$

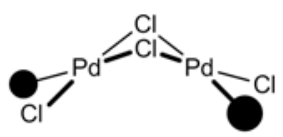

$\operatorname{VIIb}(M, M)$ VIIIb $(P, P)$
$=(M)-$ or $(P)-\mathrm{L} 1$

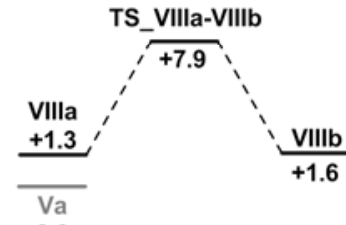

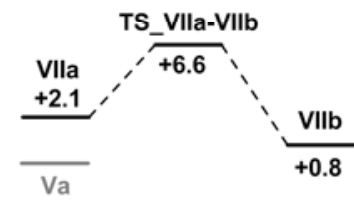

Figure 8. $(M, M)$ - and $(P, P)$-diastereomers (VIla/VIIlb, VIIla/VIIIb) of trans- $[\mathrm{PdCl}(\mu-$ $\mathrm{Cl})(\mathbf{L 1})]_{2}$ (1a) and the Gibbs free energy profiles for VIla $\leftrightarrows \mathrm{VIIb}$ and VIIIa $\leftrightarrows$ VIIIb (kcal mol $\left.{ }^{-1}, 298 \mathrm{~K}\right)$.

states TS_VIIa-VIIb and TS_VIIIa-VIIIb exhibit an almost planar $\mathrm{Pd}_{2}(\mu-\mathrm{Cl})_{2}$ core (see ESI).

The overall Gibbs free energy profile of the equilibria $\mathbf{V I I a / b \leftrightarrows V a / b \leftrightarrows V I I l a / b}$ and the structures of the affordable transition states ( $\boldsymbol{t}$-TS_Va-VIla and $\boldsymbol{t}$-TS_Vb-VIIb) for the tropoinversion in 1a is shown in Figure 9. Notably the most stable diastereomers VIIb $(M, M)$, Va $(M, P)$ and VIIla $(P, P)$ interconvert by means of a combined sequence of tropoinversions, namely $\mathbf{V I l a} \leftrightarrows \mathbf{V a}$ and $\mathbf{V b} \leftrightarrows \mathbf{V I I I b}$, and flapping of the $\mathrm{Pd}_{2}(\mu-\mathrm{Cl})_{2}$ core, namely $\mathrm{VIIa} \leftrightarrows \mathrm{VIIb}, \mathrm{Va} \leftrightarrows \mathrm{Vb}$, and $\mathrm{VIIIa} \leftrightarrows \mathrm{VIIIb}$ (Figure 9).
Like for free $\mathbf{L} 1$, taking the $\mathrm{PN}_{2}$ plane of the inverting ligand as the reference, two non-equivalent arrangements of the oxygen atom with respect to the biphenyl unit have been encountered in the calculated transition states, namely, trans $(\boldsymbol{t}$-TS) or cis (c-TS). Nevertheless, at variance with L1, the lowest barrier for both $(M, M) \leftrightarrows(M, P)$ and $(M, P) \leftrightarrows(P, P)$ tropoinversions in trans $-[\mathrm{PdCl}(\mu-\mathrm{Cl})(\mathbf{L} \mathbf{1})]_{2}$ corresponds to a trans arrangement of oxygen and biphenyl unit ( $\boldsymbol{t}$-TS_Va-VIla and $\boldsymbol{t}$ TS_Vb-VIIIb, Figure 9), which is in agreement with the reduced steric congestion around the $\mathrm{Pd}_{2}(\mu-\mathrm{Cl})_{2}$ moiety in comparison with that in the other transition states considered in this study (see ESI).

Mononuclear palladium(II) complexes. ${ }^{\S}$ The solution behaviour of the mononuclear complex trans- $\mathrm{PdCl}_{2}(\mathbf{L} \mathbf{1})_{2}(\mathbf{2 a})$ is similar to that described for $1 \mathrm{a} .{ }^{\S \S}$ Indeed, at $266 \mathrm{~K}$ the ${ }^{31} \mathrm{P}\left\{{ }^{1} \mathrm{H}\right\}$ NMR spectrum of $2 a$ contains four signals [119.1, 10\% ( $M, M$ or $P, P), 117.2,51 \%(P, P$ or $M, M) ; 116.7$ and $115.9 \mathrm{ppm}$, total $39 \%$ $(M, P)]$ suggesting the presence of the three diastereomers $(M, M)-2 \mathbf{a},(M, P)-2 \mathbf{a}$ and $(P, P)-2 \mathbf{a}$ (Figure 10). Also, two nonequivalent NMe groups have been observed for both the $(M, M)$ - and $(P, P)$-diastereomers $\left(\delta_{H}, \delta_{\mathrm{C}}: 3.39,41.3 ; 3.23,41.8\right.$; and $3.33,39.8 ; 3.31,42.4)$, whereas two pairs of nonequivalent $\mathrm{NMe}$ groups have been assigned to the diastereomer $(M, P)-2 \mathrm{a}\left(\delta_{\mathrm{H}}, \delta_{\mathrm{C}}: 3.44,42.8,3.42,42.3\right.$; and 3.40, $40.2,3.34,39.7)$, along with the corresponding ${ }^{1} \mathrm{H}$ signals for the POCH protons $\left(\delta_{\mathrm{H}}, \delta_{\mathrm{C}}: 5.22,79.7 ; 5.36,80.0 ; 5.53,78.9\right.$; $5.57,79.2)$

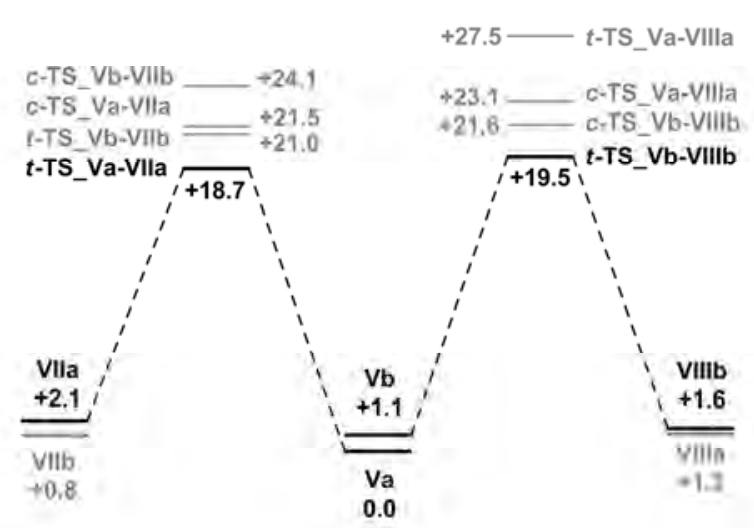

(A)

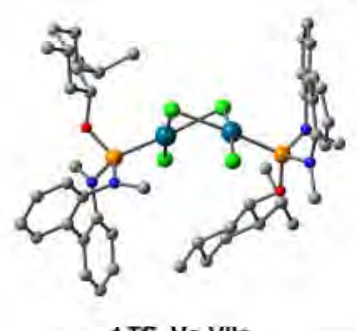

t-TS_Va-VIla

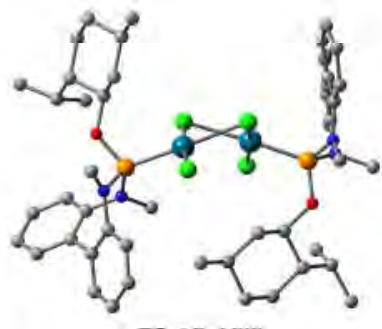

AS_VG-VIIIt

(B)

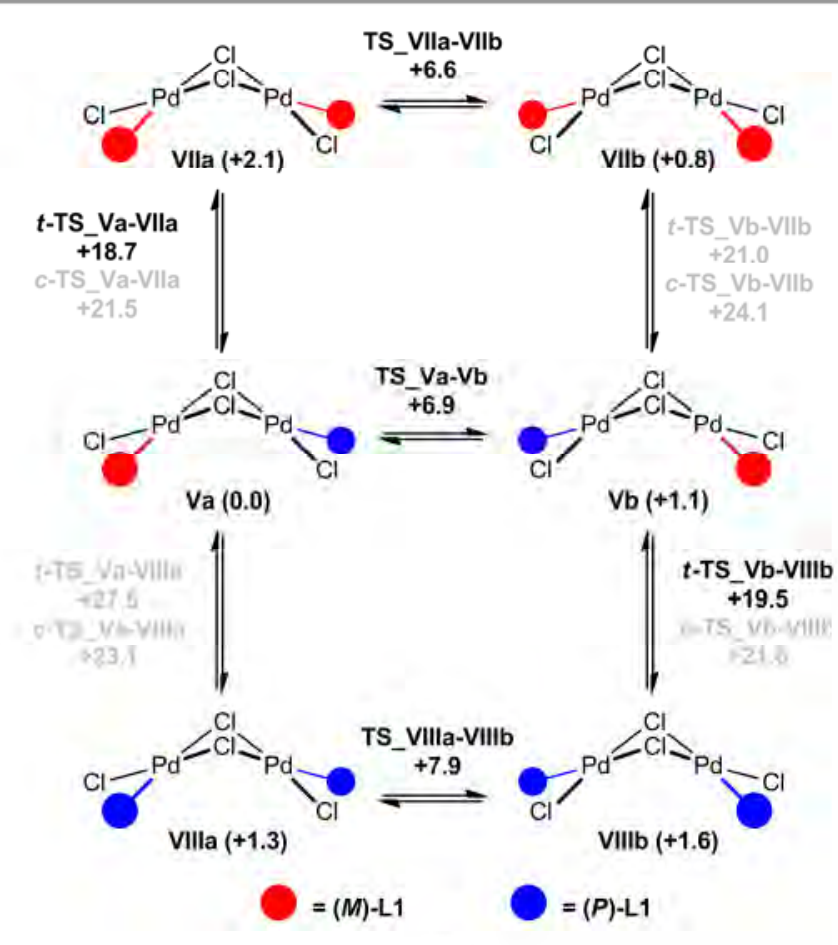

(C)

Figure 9. (A) Gibbs free energy profile for the tropo-inversion in trans-[PdCl( $\mu$-Cl)(L1) $]_{2}\left(\mathrm{kcal}_{\mathrm{mol}}{ }^{-1}, 298 \mathrm{~K}\right)$. (B) Calculated structures of the transition states $t$-TS_Va-VIla and $t$-TS_Vb-VIIIb. (C) Overall reaction scheme of tropo-inversions and flapping of the $\mathrm{Pd}_{2}(\mu-\mathrm{Cl})_{2}$ core. 


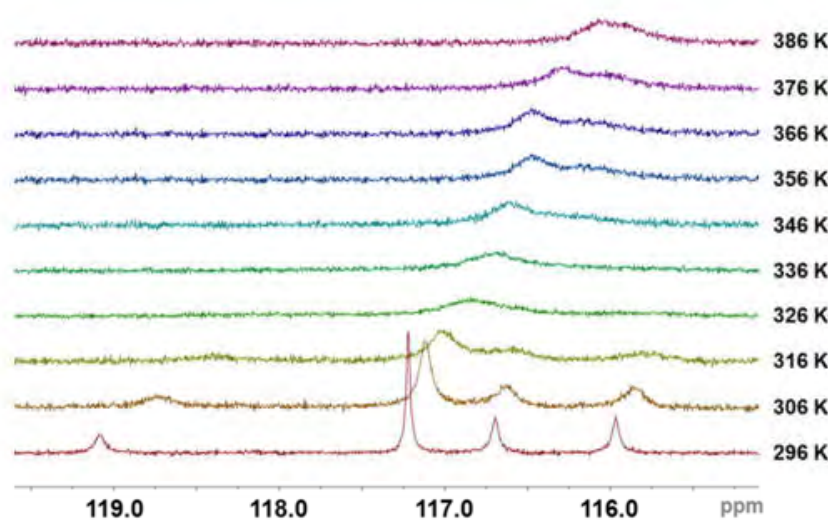

Figure 10. Vertically stacked ${ }^{31} \mathrm{P}\left\{{ }^{1} \mathrm{H}\right\}$ NMR spectra of $\mathbf{2 a}$ in toluene- $d_{8}$ at different temperatures.

The line width observed in the ${ }^{31} \mathrm{P}\left\{{ }^{1} \mathrm{H}\right\}$ NMR spectrum at $296 \mathrm{~K}$ $\left(\Delta v_{1 / 2}=8 \mathrm{~Hz}\right.$, av. $)$ and the evolution of the signals on rising the temperature indicate that the tropo-inversion is operative in solution (Figure 10). The line shape analysis ${ }^{12}$ was carried out using two independent constants (see ESI-Table S3), namely one for $(M, M)-\mathbf{2} \mathbf{a} \leftrightarrows(M, P)-\mathbf{2} \mathbf{a}$ and the other for $(M, P)-\mathbf{2} \mathbf{a} \leftrightarrows(P, P)-$ 2a, and the activation parameters were obtained by the Eyring plots (i: $\Delta H^{\ddagger}=+14.6 \pm 0.1 \mathrm{kcal} \mathrm{mol}^{-1} ; \Delta S^{\ddagger}=-3.7 \pm 0.3 \mathrm{cal} \mathrm{mol}^{-1} \mathrm{~K}^{-1}$; $\Delta G^{\ddagger}{ }_{298 \mathrm{~K}}=+15.7 \pm 0.2 \mathrm{kcal} \mathrm{mol}^{-1}$; ii: $\Delta H^{\ddagger}=14.83 \pm 0.09 \mathrm{kcal} \mathrm{mol}^{-1}$; $\Delta S^{\ddagger}=-2.7 \pm 0.3 \mathrm{cal} \mathrm{mol}^{-1} \mathrm{~K}^{-1}, \Delta G^{\ddagger} 298 \mathrm{~K}=+15.7 \pm 0.2 \mathrm{kcal} \mathrm{mol}^{-1}$, see ESI-Figure S6). Similarly to $1 \mathbf{a}$, the small values of activation enthalpy and the negative values of activation entropy suggest that the tropo-inversion is non-dissociative in $\mathbf{2} \mathbf{a}$, as well. Further, like for $\mathbf{1 a}$, also in $\mathbf{2 a}$ the inversion of one ligand is scarcely affected by the configuration of the non-inverting ligand and the activation barrier of the coordinated ligand is higher than that of the free ligand, probably for steric reasons. DFT calculations were carried out in order to shed light on the fluxional processes of $\mathbf{2 a}$ in solution. Figure 11 shows the calculated structures of the diastereoisomers IXa $(M, M)$, Xa-c $(M, P)$ and Xla-b $(P, P)$. As a common characteristic, a mutual trans arrangement of the oxygen atoms with respect to the equatorial plane is generally adopted and the absolute value of dihedral angle O-P...P-O is approx. $160^{\circ}$ (av.). It is worth a mention that, at variance with $\mathbf{1 a}$, rotamers of the $(P, M)$ - and $(P, P)$-diastereomers have been considered. Indeed $\mathbf{X a}, \mathbf{X b}$ and $\mathbf{X c}$, on one hand, and XIa and XIb, on the other, differ as for the dihedral angles Pd-P-O-CH $(\alpha)$ and $\mathrm{P}-\mathrm{O}-\mathrm{C}^{\mathrm{CH}}-\mathrm{C}^{\mathrm{CH} 2}(\beta)$ (see ESI for the structures of all the rotamers considered in this study). Similarly to $\mathbf{L} \mathbf{1}$ and $\mathbf{1 a}$, the rotation around the $\mathrm{C}\left(\mathrm{sp}^{2}\right)-\mathrm{C}\left(\mathrm{sp}^{2}\right)$ bond between the two phenyl groups should be responsible for the tropo-inversion of $\mathbf{L 1}$ in trans- $\mathrm{PdCl}_{2}(\mathbf{L 1})_{2}(\mathbf{2 a})$. Indeed accessible transition states featuring almost planar biphenyl units were encountered, and taking the N-P-N plane of the inverting ligand as the reference, trans and cis arrangements of the oxygen atom and the inverting biphenyl unit were observed (see ESI). In an ideal sequential picture starting from the $(M, M)$-diastereomer IXa, the only affordable transition
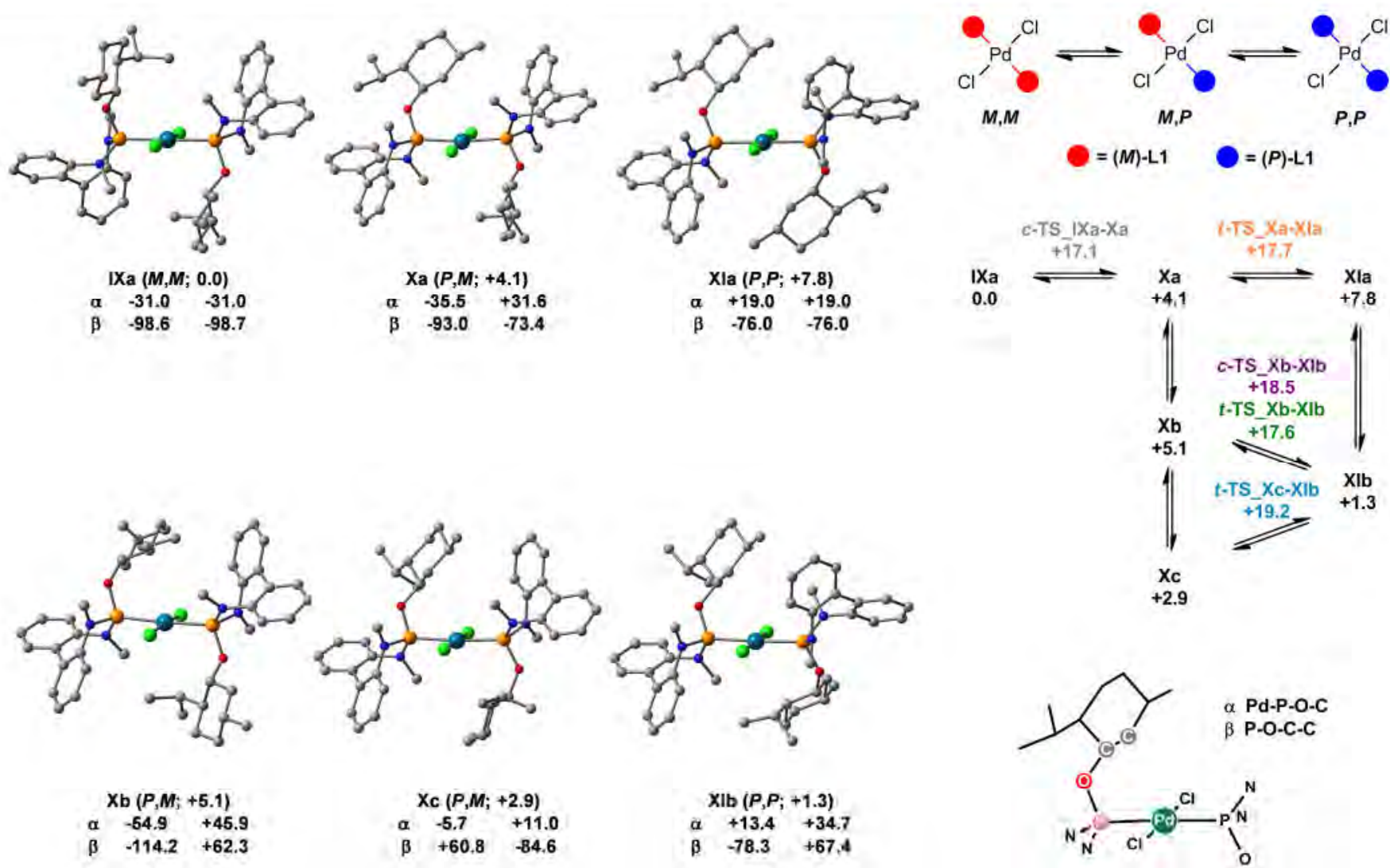

Figure 11. (top) Selected structures of diastereomers of $\mathbf{2 a}$ and relative Gibbs free energies $\left(\mathrm{kcal}_{\mathrm{mol}} \mathrm{m}^{-1}\right.$ ). For each ligand and structure, the dihedral angles Pd-P-O-C ( $\alpha$ ) and Pd-O$\mathrm{C}^{\mathrm{CH}}-\mathrm{C}^{\mathrm{CH} 2}(\beta)$ are given (deg). (bottom) Overall reaction scheme for the tropo-inversion of $\mathrm{L} 1$ in $\mathbf{2 a}$ and activation Gibbs free energies (kcal mol ${ }^{-1}$, relative to IXa). 
state for the tropo-inversion $(M, M) \leftrightarrows(P, M)$ is $\boldsymbol{t}$-TS_IXa-Xa $\left(+17.1 \mathrm{kcal} \mathrm{mol}^{-1}\right)$ and $\mathbf{X a}$ forms as a result of the inversion. Next, Xa could convert into the more stable rotamer $\mathbf{X c}$ by means of the rotations around the $\mathrm{P}-\mathrm{O}$ and $\mathrm{O}-\mathrm{C}$ bonds ( $c f . \alpha$ and $\beta$ in Figure 11). At variance with $(M, M) \leftrightarrows(P, M)$ the tropoinversion $(P, M) \leftrightarrows(P, P)$ may take place via different pathways. Indeed the transition states $\boldsymbol{t}$-TS_Xa-XIa, $\boldsymbol{t}$-TS_Xb-XIb, $\boldsymbol{c}$-TS_XbXIb

and $\boldsymbol{c}$-TS_Xc-XIb are accessible (Figure 11). Notably, similarly to $\mathbf{X a}$, once $\mathbf{X l a}$ forms as the outcome of the inversion process $\mathbf{X} \mathbf{a} \rightarrow \mathbf{X I a}, \mathbf{X I a}$ should convert into XIc by means of the rotations around the $\mathrm{P}-\mathrm{O}$ and the $\mathrm{O}-\mathrm{C}$ bonds. Any attempt to estimate the barriers of the transformations $\mathbf{X a} \rightarrow \mathbf{X c}$ and $\mathbf{X} \mathbf{I} \rightarrow \mathbf{X} \mathbf{l b}$ was unsuccessful, nevertheless they are reasonably expected to be smaller than those of the tropo-inversion. Figure 11 shows the overall reaction scheme for the tropo-inversion in $\mathbf{2 a}$. For the sake of comparison, additional rotamers as well as the transition states found at higher energies are shown in ESI.

The deoxycholic derivative $\mathbf{2 b}$ exhibit a solution behaviour similar to $2 \mathrm{a}$ (see ESI-Figure S2). At $293 \mathrm{~K}$ two overlapping ${ }^{31} \mathrm{P}$ resonances were observed at $113.98\left(\Delta \mathrm{v}_{1 / 2}=25 \mathrm{~Hz}, 64 \%\right)$ and $114.03 \mathrm{ppm}\left(\Delta \mathrm{v}_{1 / 2}=120 \mathrm{~Hz}, 36 \%\right)$, while at $203 \mathrm{~K}$ the ${ }^{31} \mathrm{P} \mathrm{NMR}$ spectrum shows four ${ }^{31} \mathrm{P}$ signals (111.8, 5 \%; 114.9, $74 \%$; 115.5 and $113.9,21 \%)$. Also at $338 \mathrm{~K}$ one well shaped ${ }^{31} \mathrm{P}$ resonance (113.4 ppm, 6.0 Hz) was observed along with one ${ }^{1} \mathrm{H}$ signal for $\mathrm{POCH}\left(\delta_{\mathrm{H}} 4.84 ; \delta_{\mathrm{C}} 80.3 \mathrm{ppm}\right)$ and one ${ }^{1} \mathrm{H}$ signals for the exchanging NMe groups $\left(\delta_{\mathrm{H}} 3.55 ; \delta_{\mathrm{C}} 41.5 \mathrm{ppm}\right)$.

Interestingly at $193 \mathrm{~K}$ additional minor signals can be observed in the ${ }^{31} \mathrm{P}$ NMR suggesting that minor rotamers/conformers of the above mentioned diastereomers are observed as a consequence of the higher steric demand of the deoxycholic substituents making slower the rotational/conformational equilibria (see ESI-Figure S2).

\section{Conclusions}

The tropo-inversion of the biphenyl moiety in $\mathbf{L} \mathbf{1}$ and $\mathbf{L} \mathbf{2}$, and of their palladium complexes trans- $\mathrm{PdCl}_{2}(\mathrm{~L})_{2}(\mathbf{2 a} / \mathbf{2} \mathbf{b})$ and trans$[\mathrm{Pd}(\mu-\mathrm{Cl}) \mathrm{Cl}(\mathrm{L})]_{2}(\mathbf{1} \mathbf{a} / \mathbf{1} \mathbf{b})$ have been investigated.

In all the cases NMR spectroscopy indicates that the tropoinversion is operative at room temperature and all the diastereomers are present in solution. As for L1, L2, trans$[\mathrm{Pd}(\mu-\mathrm{Cl}) \mathrm{Cl}(\mathbf{L 1})]_{2} \quad(\mathbf{1 a})$, and trans- $\mathrm{PdCl}_{2}(\mathbf{L 1})_{2} \quad(\mathbf{2 a})$, the ${ }^{31} \mathrm{P}\left\{{ }^{1} \mathrm{H}\right\}$ NMR line shape analysis indicates that the mechanism of the tropo-inversion is non-dissociative and that higher activation barriers are observed upon coordination of $\mathbf{L} \mathbf{1}$ to palladium (1a and 2a). Remarkably the inversion of one ligand in both $\mathbf{1 a}$ and $2 a$ is scarcely affected by the configuration of the noninverting ligand. DFT calculations have pointed out that two transition states are possible. As a matter of fact, both a trans and a cis arrangement of the oxygen atom with respect to the nitrogen-phosphorus-nitrogen plane of the inverting biphenyl group can be observed. Depending on the steric congestion either the cis or the trans arrangement is the most favorable. Based on the DFT calculations, additional conformational/rotational equilibria for the diastereomers of $\mathbf{1 a} / \mathbf{1} \mathbf{b}$ or $\mathbf{2 a / 2} \mathbf{b}$ should be operative in solution.

\section{Experimental}

Triethylamine and pyridine were refluxed over calcium hydride and distilled. Dichloromethane, toluene and hexane were obtained oxygen- and water-free from a Solvent Purification System (Innovative Technologies). Phosphorus trichloride (Aldrich) was distilled and degassed by freeze-pump-thaw cycling. Benzene- $d_{6}$ and toluene- $d_{8}$ were dried over sodium and degassed by freeze-pump-thaw cycling. The other commercial reagents were used as received without further purification. $N, N^{\prime}$-dimethyl-1,1'-biphenyl-2,2'-diamine ${ }^{8 \mathrm{c}}$ (C1) and $\mathrm{PdCl}_{2}(\mathrm{NCPh})_{2}{ }^{20}$ were prepared as previously reported. NMR spectra were acquired on a Bruker AV400 spectrometer (400.13 MHz for ${ }^{1} \mathrm{H}$ ). The chemical shift values are referred to $\mathrm{SiMe}_{4}\left({ }^{1} \mathrm{H}\right.$ and $\left.{ }^{13} \mathrm{C}\right)$ and $\mathrm{H}_{3} \mathrm{PO}_{4}\left({ }^{31} \mathrm{P}\right)$ as external standards. The following abbreviations were used: singlet (s), doublet (d), triplet (t), quartet (q), nonet $(n)$, multiplet $(m)$, doublet-of-doublets (dd), doublet-of-doublets-of-doublets (ddd), triplet-of-doublets $(\mathrm{td})$, doublet-of-triplet $(\mathrm{dt})$, broad signal (bs). Due to the fluxional behaviour of $\mathbf{1 a} / \mathbf{b}$ and $\mathbf{2 a} \mathbf{a} \mathbf{b}$, broad and partially merged ${ }^{1} \mathrm{H}$ and ${ }^{13} \mathrm{C}$ signals were observed at room temperature thus preventing any reliable assignation to be carried out at that temperature. On this basis, the NMR data of $1 \mathrm{a}$ and $\mathbf{2 a}$ are given at $266 \mathrm{~K}$ and $233 \mathrm{~K}$, respectively, namely in the slow exchange limit, where sharp ${ }^{1} \mathrm{H}$ and ${ }^{13} \mathrm{C}$ signals were observed. On the other hand, as for $\mathbf{1 b}$ and $\mathbf{2} \mathbf{b},{ }^{1} \mathrm{H}$ and ${ }^{13} \mathrm{C}$ sharp signals were observed only in the fast exchange limit, thus their NMR data are given at $366 \mathrm{~K}$ and $338 \mathrm{~K}$, respectively. The diffusion experiments were carried out at $298 \mathrm{~K}$ using the stimulated echo pulse sequence ${ }^{21}$ and the data were analysed using the T1/T2 relaxation module of the suite Bruker Topspin ${ }^{\circledR}$. Carbon, hydrogen and nitrogen analyses were performed using a Perkin-Elmer 240B microanalyzer.

\section{Synthesis of L1 and L2}

L1. At $273 \mathrm{~K}$ a solution of $\mathrm{PCl}_{3}(1.3 \mathrm{~mL}, 15 \mathrm{mmol})$ in toluene (15 $\mathrm{mL}$ ) was added dropwise to a solution of $N, N^{\prime}$-dimethyl-1, $1^{\prime}$ diphenyl-2,2'diamine (C1, $2.01 \mathrm{~g}, 9.47 \mathrm{mmol})$ and pyridine (2.3 mL, $28 \mathrm{mmol}$ ) in toluene $(55 \mathrm{~mL})$. After $1 \mathrm{~h}$ stirring at room temperature, the resulting precipitate was filtered off and the volatiles were evaporated from the filtrate under reduced pressure giving 6-chloro-5,7-dimethyl-6,7-dihydro-5Hdibenzo[d,f][1,3,2]diazaphsphepine (C2, $1.97 \mathrm{~g}, 276.70 \mathrm{~g} \mathrm{~mol}^{-1}$, $75 \%$ yield, $\left.\delta_{p} 206.6,298 \mathrm{~K}, \mathrm{C}_{6} \mathrm{D}_{6}\right)$ as an oil which was used without further purifications. Compound $\mathbf{C 2}$ was dissolved in toluene $(20 \mathrm{~mL})$ and pyridine $(1.7 \mathrm{~mL}, 21 \mathrm{mmol})$ was added at room temperature. The mixture was cooled to $213 \mathrm{~K}$ and a solution of (-)-menthol $(1.11 \mathrm{~g}, 7.10 \mathrm{mmol})$ in toluene $(10 \mathrm{~mL})$ was added dropwise. The resulting mixture was warmed up to room temperature and stirred for $14 \mathrm{~h}$. The precipitate was filtered off and all volatiles were removed from the filtrate under vacuum, giving $\mathbf{L 1}$ as colourless solid (2.80 g, $99 \%$ yield). Anal. calcd for $\mathrm{C}_{24} \mathrm{H}_{33} \mathrm{~N}_{2} \mathrm{OP}$ (396.51 $\mathrm{g} \mathrm{mol}^{-1}$ ): C, 72.70; $\mathrm{H}, 8.39$; $\mathrm{N}, 7.07$. Found: C, 72.69; $\mathrm{H}, 8.38 ; \mathrm{N}, 7.05$. 


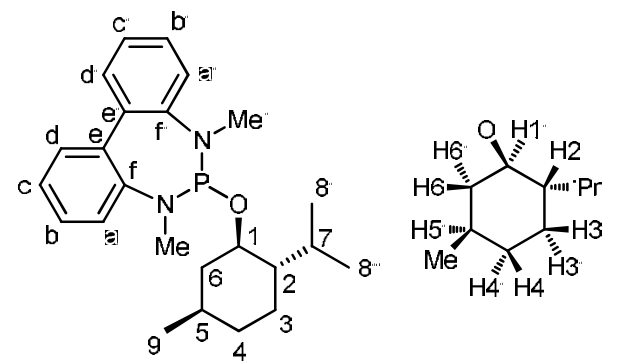

${ }^{1} \mathrm{H}$ NMR (298 K, toluene- $\left.d_{8}\right), \delta: 7.25\left(\mathrm{~d},{ }^{3} \mathrm{~J}_{\mathrm{HH}}=7.6 \mathrm{~Hz}, 2 \mathrm{H}, \mathrm{d}, \mathrm{d}^{\prime}\right)$, 7.20-7.16 (m, 4H, a, a', b, b') , 7.06-7.02 (2H, c, c') 3.89 (ddt, $\left.{ }^{3} J_{\mathrm{HP}}=10.3 \mathrm{~Hz},{ }^{3} \mathrm{~J}_{\mathrm{HH}}=4.5,4.3 \mathrm{~Hz}, 1 \mathrm{H}, 1^{\prime}\right), 2.87\left(\mathrm{~d},{ }^{3} J_{\mathrm{HP}}=11.7 \mathrm{~Hz}, 3 \mathrm{H}\right.$, $\left.\mathrm{NMe}^{\prime}\right), 2.82\left(\mathrm{~d},{ }^{3} J_{\mathrm{HP}}=10.7 \mathrm{~Hz}, 3 \mathrm{H}, \mathrm{NMe}\right), 2.54(\mathrm{~m}, 1 \mathrm{H}, 7), 2.22$ $\left(\mathrm{m}, 1 \mathrm{H}, 6^{\prime}\right), 1.60-1.52\left(\mathrm{~m}, 2 \mathrm{H}, 3,4^{\prime}\right), 1.35-1.25\left(\mathrm{~m}, 2 \mathrm{H}, 5^{\prime}, 2\right)$, $1.16(\mathrm{~m}, 1 \mathrm{H}, 6), 0.94\left(\mathrm{~d},{ }^{3} \mathrm{~J}_{\mathrm{HH}}=7.0 \mathrm{~Hz}, 9\right), 0.91\left(\mathrm{~d},{ }^{3} \mathrm{~J}_{\mathrm{HH}}=7.2 \mathrm{~Hz}, 8\right)$, $0.91(\mathrm{~m}, 4), 0.77\left(\mathrm{~m}, 1 \mathrm{H}, 3^{\prime}\right) .{ }^{13} \mathrm{C}\left\{{ }^{1} \mathrm{H}\right\}$ NMR $\left(298 \mathrm{~K}\right.$, toluene- $\left.d_{8}\right)$, $\delta: 146.9$ (f), $146.3\left(f^{\prime}\right), 137.5\left(e, e^{\prime}\right), 129.82\left(d / d^{\prime}\right), 129.80\left(d / d^{\prime}\right)$, $128.2\left(\mathrm{a}, \mathrm{a}^{\prime}\right), 128.1$ (b, b'), $124.5\left(\mathrm{c} / \mathrm{c}^{\prime}\right), 124.5\left(\mathrm{c} / \mathrm{c}^{\prime}\right), 75.4$ (d, $\left.{ }^{2} J_{C P}=21.6 \mathrm{~Hz}, 1\right), 49.3\left(\mathrm{~d},{ }^{3} J_{\mathrm{CP}}=5.0 \mathrm{~Hz}, 2\right), 44.9\left(\mathrm{~d},{ }^{3} J_{\mathrm{CP}}=7.5 \mathrm{~Hz}, 6\right)$, $38.1\left(\mathrm{~d},{ }^{2} J_{\mathrm{CP}}=38.5 \mathrm{~Hz}, \mathrm{NMe}^{\prime}\right), 37.4\left(\mathrm{~d},{ }^{2} J_{\mathrm{CP}}=33.4 \mathrm{~Hz}, \mathrm{NMe}\right), 34.6$ (3), 32.0 (5), 25.3 (7), 23.2 (4), 22.5 (8'), 21.3 (9), 15.9 (8'). ${ }^{31} \mathrm{P}\left\{{ }^{1} \mathrm{H}\right\}$ NMR $\left(298 \mathrm{~K}\right.$, toluene- $\left.d_{8}\right), \delta: 175.5$.

L2. Ligand L2 was synthesized according to a modification of the previously reported procedure. ${ }^{8 c}$ Phosphorus trichloride (1.2 $\mathrm{mL}, 14 \mathrm{mmol}$ ) was added to a solution of 3-acetoxy deoxycholic methyl ester $(2.00 \mathrm{~g}, 4.46 \mathrm{mmol})$ in dichloromethane $(10 \mathrm{~mL})$. After $24 \mathrm{~h}$ stirring all volatiles were removed in vacuum and the resulting colourless solid $\left(\mathbf{C} 3, \delta_{\mathrm{P}}\right.$ 181.6, $\left.298 \mathrm{~K} \mathrm{C}_{6} \mathrm{D}_{6}\right)$ was dissolved in toluene $(5 \mathrm{~mL})$. Afterwards a solution of $N, N^{\prime}$-dimethyl-1,1'-biphenyl-2,2'-diamine (C1, $946 \mathrm{mg}, 4.46 \mathrm{mmol}$ ) and triethylamine (1.9 mL, $14 \mathrm{mmol})$ in 25 $\mathrm{mL}$ of toluene was added. The resulting mixture was refluxed for $16 \mathrm{~h}$ and then filtered. All volatiles were removed from the filtrate in vacuum yielding a colourless solid $(2.98 \mathrm{~g}, 97 \%$ yield). Anal. calcd for $\mathrm{C}_{41} \mathrm{H}_{57} \mathrm{~N}_{2} \mathrm{O}_{5} \mathrm{P}\left(688.89 \mathrm{~g} \mathrm{~mol}^{-1}\right)$ : $\mathrm{C}, 71.48 ; \mathrm{H}$, 8.34; N, 4.07. Found: C, 71.59; H, 8.37; N, 4.06.

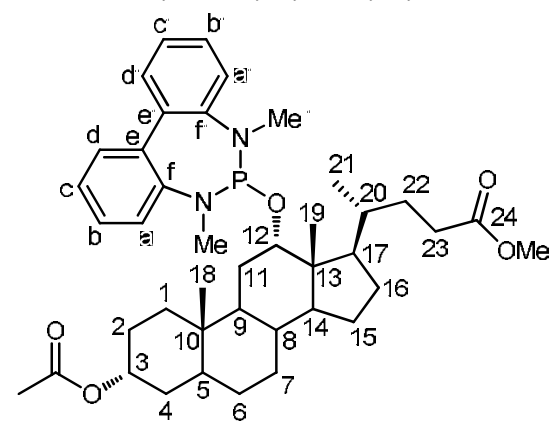

${ }^{1} \mathrm{H}$ NMR (298 K, $\left.\mathrm{C}_{6} \mathrm{D}_{6}\right), \delta: 7.43\left(\mathrm{dd},{ }^{3} J_{\mathrm{HH}}=7.6 \mathrm{~Hz},{ }^{4} J_{\mathrm{HH}}=1.6 \mathrm{~Hz}, 1 \mathrm{H}\right.$, d), $7.38\left(\mathrm{dd},{ }^{3} J_{\mathrm{HH}}=7.5 \mathrm{~Hz},{ }^{4} J_{\mathrm{HH}}=1.6 \mathrm{~Hz}, 1 \mathrm{H}, \mathrm{d}^{\prime}\right), 7.31$ (ddd, $\left.{ }^{3} J_{\mathrm{HH}}=7.5,6.5 \mathrm{~Hz},{ }^{4} J_{\mathrm{HH}}=1.6 \mathrm{~Hz}, \mathrm{~b}^{\prime}\right), 7.29$ (ddd, ${ }^{3} J_{\mathrm{HH}}=7.5,7.4 \mathrm{~Hz}$, $\left.{ }^{4} J_{\mathrm{HH}}=1.6 \mathrm{~Hz}, \mathrm{~b}\right), 7.26\left(\mathrm{dd},{ }^{3} J_{\mathrm{HH}}=7.5 \mathrm{~Hz},{ }^{4} J_{\mathrm{HH}}=1.4 \mathrm{~Hz}, \mathrm{a} / \mathrm{a}^{\prime}\right), 7.18$ (ddd, ${ }^{3} J_{\mathrm{HH}}=7.6,7.4 \mathrm{~Hz},{ }^{4} J_{\mathrm{HH}}=1.4 \mathrm{~Hz}, \mathrm{c}$ ), 7.15 (ddd, ${ }^{3} J_{\mathrm{HH}}=7.5,6.5$ $\left.\mathrm{Hz},{ }^{4} J_{\mathrm{HH}}=1.4 \mathrm{~Hz}, c^{\prime}\right), 4.82(\mathrm{~m}, 1 \mathrm{H}, 3), 4.32\left(\mathrm{dt},{ }^{3} J_{\mathrm{HP}}=6.2 \mathrm{~Hz}\right.$, $\left.{ }^{3} J_{\mathrm{HH}}=2.5 \mathrm{~Hz}, 1 \mathrm{H}, 12\right), 3.41\left(\mathrm{~s}, 3 \mathrm{H}, \mathrm{OCH}_{3}\right), 2.90\left(\mathrm{~d},{ }^{3} J_{\mathrm{HP}}=11.8\right.$ $\mathrm{Hz}, 3 \mathrm{H}, \mathrm{NMe}), 2.83\left(\mathrm{~d}, 3^{3} \mathrm{HP}_{\mathrm{HP}}=12.0 \mathrm{~Hz}, 3 \mathrm{H}, \mathrm{NMe}^{\prime}\right), 2.29(\mathrm{~m}, 1 \mathrm{H}$, 23), $2.22(\mathrm{~m}, 1 \mathrm{H}, 23), 1.93(\mathrm{~m}, 2 \mathrm{H}, 17,22), 1.86-1.75(\mathrm{~m}, 5 \mathrm{H}, 2$, $4,8 / 9,15,16), 1.72\left(\mathrm{~s}, 3 \mathrm{H}, \mathrm{CH}_{3} \mathrm{C}=\mathrm{O}\right), 1.72-1.49(\mathrm{~m}, 6 \mathrm{H}, 1,2 / 4$,
$6 / 7,11,14,15), 1.46-1.07(\mathrm{~m}, 9 \mathrm{H}, 2 / 4,5,6 / 7,8 / 9,11,16,20$, 22), $1.03\left(\mathrm{~d},{ }^{3} \mathrm{~J}_{\mathrm{HH}}=6.2 \mathrm{~Hz}, 3 \mathrm{H}, 21\right), 1.03-0.94(\mathrm{~m}, 2 \mathrm{H}, 6,7), 0.85$ $(\mathrm{m}, 1 \mathrm{H}, 1), 0.82(\mathrm{~s}, 3 \mathrm{H}, 18), 0.62(\mathrm{~s}, 3 \mathrm{H}, 19) .{ }^{13} \mathrm{C}\left\{{ }^{1} \mathrm{H}\right\}$ NMR $(298$ $\left.\mathrm{K}, \mathrm{C}_{6} \mathrm{D}_{6}\right), \delta: 173.7(24), 169.6(\mathrm{C}=\mathrm{O}), 130.6\left(\mathrm{~d}^{\prime}\right), 130.4(\mathrm{~d}), 128.3$ $\left(\mathrm{b} / \mathrm{b}^{\prime}\right), 128.2\left(\mathrm{~b} / \mathrm{b}^{\prime}\right), 124.7\left(\mathrm{c} / \mathrm{c}^{\prime}\right), 124.4\left(\mathrm{c} / \mathrm{c}^{\prime}\right), 123.8\left(\mathrm{~d},{ }^{3} J_{\mathrm{CP}}=0.8\right.$ $\left.\mathrm{Hz}, \mathrm{a} / \mathrm{a}^{\prime}\right), 123.5\left(\mathrm{~d},{ }^{3} \mathrm{~J}_{\mathrm{CP}}=0.9 \mathrm{~Hz}, \mathrm{a} / \mathrm{a}^{\prime}\right), 77.5\left(\mathrm{~d},{ }^{2} \mathrm{~J}_{\mathrm{CP}}=12.2 \mathrm{~Hz}, 12\right)$, 74.0 (3), $51.0\left(\mathrm{OCH}_{3}\right), 48.2$ (14), 46.4 (17), 42.1 (5), 37.7 (d, ${ }^{2} J_{\mathrm{CP}}=34.9 \mathrm{~Hz}, \mathrm{NMe}$ ), $37.6\left(\mathrm{~d},{ }^{2} \mathrm{~J}_{\mathrm{CP}}=34.1 \mathrm{~Hz}, \mathrm{NMe}\right), 36.3(20), 36.1$ (8/9), 35.4 (1), 33.9 (8/9), 32.7 (2/4), 31.4 (22), 31.3 (23), 28.1 (16), $27.52(2 / 4), 27.45\left(d,{ }^{3} J_{C P}=7.2 \mathrm{~Hz}, 11\right), 27.0\left(d,{ }^{5} J_{C P}=3.9 \mathrm{~Hz}\right.$, 15), 26.7 (6/7), $24.3(6 / 7), 23.2$ (18), 21.1 ( $\mathrm{Me}(\mathrm{C}=0)$ ), 18.1 (d, $\left.{ }^{6} J_{C P}=6.2 \mathrm{~Hz}, 21\right), 12.8(19) .{ }^{31} \mathrm{P}\left\{{ }^{1} \mathrm{H}\right\} \mathrm{NMR}\left(298 \mathrm{~K}, \mathrm{C}_{6} \mathrm{D}_{6}\right), \delta: 164.9$.

\section{Synthesis of trans- $[\mathrm{Pd}(\mu-\mathrm{Cl}) \mathrm{Cl}(\mathrm{L})]_{2}(\mathrm{~L}=\mathrm{L} 1,1 \mathrm{a} ; \mathrm{L}=\mathrm{L2}, 1 \mathrm{~b})$}

A colorless solution of the ligand $(0.75 \mathrm{mmol})$ in toluene $(6 \mathrm{~mL})$ was added to a red solution of $\mathrm{PdCl}_{2}(\mathrm{NCPh})_{2}(0.75 \mathrm{mmol})$ in toluene $(30 \mathrm{~mL})$. After $1 \mathrm{~h}$ stirring, the solvent was removed under reduced pressure and the deep yellow-orange solid was washed with hexane $(3 \times 3 \mathrm{~mL})$ and finally dried under vacuum. Trans- $[\mathrm{Pd}(\boldsymbol{\mu}-\mathrm{Cl}) \mathrm{Cl}(\mathrm{L1})]_{\mathbf{2}}$ (1a, $407.5 \mathrm{mg}, 95 \%$ yield). Anal. calcd for $\mathrm{C}_{48} \mathrm{H}_{66} \mathrm{Cl}_{4} \mathrm{~N}_{4} \mathrm{O}_{2} \mathrm{P}_{2} \mathrm{Pd}_{2}\left(1147.67 \mathrm{~g} \mathrm{~mol}^{-1}\right): \mathrm{C}, 50.23 ; \mathrm{H}, 5.80 ; \mathrm{N}$, 4.88. Found: $\mathrm{C}, 50.24 ; \mathrm{H}, 5.78 ; \mathrm{N}, 4.87$. NMR data are given according to the numbering scheme used for $\mathbf{L 1}$ (vide supra). ${ }^{1} \mathrm{H}$ NMR $\left(233 \mathrm{~K}\right.$, toluene- $\left.d_{8}\right), \delta: 7.93\left(\mathrm{~d},{ }^{3} \mathrm{~J}_{\mathrm{HH}}=9.4 \mathrm{~Hz}, \mathrm{a}\right), 7.91(\mathrm{~d}$, $\left.{ }^{3} J_{\mathrm{HH}}=8.7 \mathrm{~Hz}, \mathrm{a}\right), 7.84\left(\mathrm{~d},{ }^{3} J_{\mathrm{HH}}=8.0 \mathrm{~Hz}\right), 7.22-6.89(\mathrm{~m}), 5.86-5.60$ $\left(\mathrm{m}, 1^{\prime}\right), 4.40\left(\mathrm{~d},{ }^{3} J_{\mathrm{HH}}=9.1 \mathrm{~Hz}, 6^{\prime}\right), 4.32\left(\mathrm{~d},{ }^{3} \mathrm{~J}_{\mathrm{HH}}=9.9 \mathrm{~Hz}, 6^{\prime}\right), 3.16$ (d, $\left.{ }^{3} J_{\mathrm{HP}}=12.9 \mathrm{~Hz}, \mathrm{NMe}\right), 3.15\left(\mathrm{~d},{ }^{3} J_{\mathrm{HP}}=12.5 \mathrm{~Hz}, \mathrm{NMe}\right), 3.09$ (d, $\left.{ }^{3} J_{\mathrm{HP}}=12.8 \mathrm{~Hz}, \mathrm{NMe}\right), 3.02\left(\mathrm{~d},{ }^{3} J_{\mathrm{HP}}=12.4 \mathrm{~Hz}, \mathrm{NMe}\right), 2.97$ (d, $\left.{ }^{3} J_{\mathrm{HP}}=8.3 \mathrm{~Hz}, \mathrm{NMe}^{\prime}\right), 2.95\left(\mathrm{~d},{ }^{3} J_{\mathrm{HP}}=7.0 \mathrm{~Hz}, \mathrm{NMe}^{\prime}\right), 2.94\left(\mathrm{~d},{ }^{3} J_{\mathrm{HP}}=7.8\right.$ $\left.\mathrm{Hz}, \mathrm{NMe}^{\prime}\right), 2.92\left(\mathrm{~d},{ }^{3} \mathrm{~J}_{\mathrm{HP}}=9.2 \mathrm{~Hz}, \mathrm{NMe}^{\prime}\right), 2.75(\mathrm{~m}, 7), 2.69$ (d, $\left.{ }^{3} J_{\mathrm{HH}}=9.9 \mathrm{~Hz}, 3\right), 2.68(\mathrm{~m}, 7), 2.60\left(\mathrm{~d},{ }^{3} J_{\mathrm{HH}}=9.3 \mathrm{~Hz}, 3\right), 2.25(\mathrm{~m}, 7)$, $2.19(\mathrm{~m}, 7), 1.92-0.75\left(\mathrm{~m}, 2,3^{\prime}, 4,5^{\prime}, 6,9\right), 1.79\left(\mathrm{~d},{ }^{3} \mathrm{~J}_{\mathrm{HH}}=6.3 \mathrm{~Hz}\right.$, $\left.8^{\prime}\right), 1.67\left(\mathrm{~d},{ }^{3} \mathrm{~J}_{\mathrm{HH}}=6.1 \mathrm{~Hz}, 8^{\prime}\right), 1.20\left(\mathrm{~d},{ }^{3} J_{\mathrm{HH}}=6.7 \mathrm{~Hz}, 8^{\prime}\right), 1.12(\mathrm{~d}$, $\left.{ }^{3} J_{\mathrm{HH}}=7.3 \mathrm{~Hz}, 8^{\prime}\right), 0.99\left(\mathrm{~d},{ }^{3} J_{\mathrm{HH}}=6.5 \mathrm{~Hz}, 8\right), 0.92\left(\mathrm{~d},{ }^{3} J_{\mathrm{HH}}=6.9 \mathrm{~Hz}, 8\right)$, $0.82\left(\mathrm{~d},{ }^{3} J_{\mathrm{HH}}=6.8 \mathrm{~Hz}, 8\right), 0.77\left(\mathrm{~d},{ }^{3} \mathrm{~J}_{\mathrm{HH}}=6.8 \mathrm{~Hz}, 8\right), 0.72(\mathrm{~m}, 4)$, $0.69(\mathrm{~m}, 4), 0.60(\mathrm{~m}, 4), 0.57(\mathrm{~m}, 4) .{ }^{13} \mathrm{C}\left\{{ }^{1} \mathrm{H}\right\}$ NMR $(233 \mathrm{~K}$, toluene- $\left.d_{8}\right), \delta: 143.0(\mathrm{e} / \mathrm{f}), 142.9(\mathrm{e} / \mathrm{f}), 142.8(\mathrm{e} / \mathrm{f}), 142.6(\mathrm{e} / \mathrm{f})$, 139.02 (e/f), $138.96(e / f), 138.9(e / f), 138.8$ (e/f), $135.6(e / f)$, 135.4 (e/f), 135.2 (e/f), 135.1 (e/f), 132.0, 131.8, 130.0, 129.9, 129.6, 129.4, 129.1, 128.7, 128.2, 126.3, 126.2, 126.0 130.0, 129.4, 128.7, 126.2, 82.6 (1), 82.5 (1), 81.9 (1), 81.7 (1), 49.0 $\left(d,{ }^{3} J_{C P}=7.7 \mathrm{~Hz}, 2\right), 48.7\left(d,{ }^{3} J_{C P}=7.0 \mathrm{~Hz}, 2\right), 48.2\left(d,{ }^{3} J_{\mathrm{CP}}=8.2 \mathrm{~Hz}\right.$, 2), $48.1\left(\mathrm{~d},{ }^{3} J_{\mathrm{CP}}=7.0 \mathrm{~Hz}, 2\right), 45.2(6), 45.1(6), 43.5\left(\mathrm{~d},{ }^{2} J_{\mathrm{CP}}=21.8\right.$ $\mathrm{Hz}, \mathrm{NMe}), 43.4(6), 43.1$ (d, $\left.{ }^{2} J_{\mathrm{CP}}=22.0 \mathrm{~Hz}, \mathrm{NMe}\right), 42.9$ (d, $\left.{ }^{2} J_{C P}=20.0 \mathrm{~Hz}, \mathrm{NMe}\right), 42.5\left(\mathrm{~d},{ }^{2} J_{\mathrm{CP}}=20.0 \mathrm{~Hz}, \mathrm{NMe}\right), 40.9(\mathrm{~d}$, $\left.\left.{ }^{2} J_{\mathrm{CP}}=5.9 \mathrm{~Hz}, \mathrm{NMe}\right)^{\prime}\right), 40.8\left(\mathrm{~d},{ }^{2} J_{\mathrm{CP}}=3.5 \mathrm{~Hz}, \mathrm{NMe}^{\prime}\right), 39.9\left(\mathrm{~d},{ }^{2} J_{\mathrm{CP}}=6.9\right.$ $\mathrm{Hz}, \mathrm{NMe}^{\prime}$ ), 39.7 (d, ${ }^{2} J_{\mathrm{CP}}=7.3 \mathrm{~Hz}, \mathrm{NMe}$ ), 34.5 (4), 34.3 (4), 33. 93 (4), 33.88 (4), 31.9 (5), 31.7 (5), 31.5 (5), 31.4 (5), 26.03 (7), 26.97 (7), 25.5 (7), 25.4 (7), 22.7 (9), 22.6 (9), 22.5 (9), 21.9 (8), $21.1(8), 17.64\left(8^{\prime}\right), 17.58\left(8^{\prime}\right), 16.8\left(8^{\prime}\right), 16.6\left(8^{\prime}\right) .{ }^{31} \mathrm{P}\left\{{ }^{1} \mathrm{H}\right\}$ NMR $\left(233 \mathrm{~K}\right.$, toluene- $\left.d_{8}\right), \delta: 89.5,89.2,86.7,86.2$.

Trans-[Pd( $\mu-\mathrm{Cl}) \mathrm{Cl}(\mathrm{L2})]_{\mathbf{2}}$ (1b, $633.7 \mathrm{mg}, 98 \%$ yield). Anal. calcd for $\mathrm{C}_{82} \mathrm{H}_{114} \mathrm{Cl}_{4} \mathrm{~N}_{4} \mathrm{O}_{10} \mathrm{P}_{2} \mathrm{Pd}_{2}\left(1732.42 \mathrm{~g} \mathrm{~mol}^{-1}\right): \mathrm{C}, 56.85 ; \mathrm{H}, 6.63 ; \mathrm{N}$, 3.23. Found: $\mathrm{C}, 56.67 ; \mathrm{H}, 6.61 ; \mathrm{N}, 3.22$. NMR data are given according to the numbering scheme used for $\mathbf{L 2}$ (vide supra). ${ }^{1} \mathrm{H}$ NMR (366 K, toluene- $\left.d_{8}\right), \delta: 7.69$ (bs, $\left.2 \mathrm{H}, \mathrm{a}, \mathrm{a}^{\prime}\right), 7.37$ (bs, $2 \mathrm{H}$, b, b'), $7.20\left(a, 2 H, d, d^{\prime}\right), 7.12\left(a, 2 H, c, c^{\prime}\right), 5.35$ (bs, 1H, 12), 
$4.74(\mathrm{~m}, 1 \mathrm{H}, 3), 3.47\left(\mathrm{~s}, \mathrm{OCH}_{3}\right), 3.41$ (bs, NMe, NMe'), $2.43(\mathrm{~m}$, 23), $2.34(\mathrm{~m}, 23), 2.07-0.87(\mathrm{~m}, 29 \mathrm{H}), 1.72\left(\mathrm{~s}, \mathrm{CH}_{3}(\mathrm{C}=\mathrm{O})\right), 1.26$ (bs, 21), $0.82(\mathrm{~s}, 18), 0.67(\mathrm{~s}, 19) .{ }^{13} \mathrm{C}\left\{{ }^{1} \mathrm{H}\right\}$ NMR (366 K, toluene-

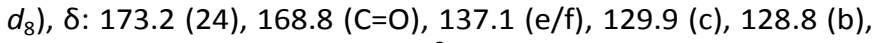
128.7 (d), 125.0 (a), 85.0 (d, $\left.{ }^{2} J_{\mathrm{CP}}=9.0 \mathrm{~Hz}, 12\right), 73.5$ (3), 50.3 $\left(\mathrm{OCH}_{3}\right), 46.9$ (14), 46.6 (17), 41.9 (5), 40.5 (NMe, NMe'), 36.3 (8/9/20), 35.0 (8/9/20), 34.7 (8/9/20), 32.6 (1), 31.9 (23), 30.9 (22), 27.8, 27.5, 27.4, 27.3, 27.1, 26.6, 24.1, 22.3 (18), 20.5 $\left(\mathrm{CH}_{3}(\mathrm{C}=\mathrm{O})\right), 18.3$ (21), 12.4 (19). ${ }^{31} \mathrm{P}\left\{{ }^{1} \mathrm{H}\right\}$ NMR (366 K, toluene$\left.d_{8}\right), \delta: 85.0$.

\section{Synthesis of trans $-\mathrm{PdCl}_{2}(\mathrm{~L})_{2}(\mathrm{~L}=\mathrm{L} 1,2 \mathrm{a} ; \mathrm{L}=\mathrm{L2}, 2 \mathrm{~b})$}

A colorless solution of the ligand $(1.0 \mathrm{mmol})$ in toluene $(8 \mathrm{~mL})$ was added to a red solution of $\mathrm{PdCl}_{2}(\mathrm{NCPh})_{2}(0.50 \mathrm{mmol})$ in toluene $(20 \mathrm{~mL})$. After $15 \mathrm{~min}$ stirring, the solvent was removed under reduced pressure and the yellow-orange solid was washed with hexane $(3 \times 4 \mathrm{~mL})$ and finally dried under vacuum.

Trans- $\mathbf{P d C l}_{\mathbf{2}}(\mathbf{L 1})_{\mathbf{2}}(\mathbf{2 a}, 470.6 \mathrm{mg}, 97 \%$ yield). Anal. calcd for $\mathrm{C}_{48} \mathrm{H}_{66} \mathrm{Cl}_{2} \mathrm{~N}_{4} \mathrm{O}_{2} \mathrm{P}_{2} \mathrm{Pd}\left(970.35 \mathrm{~g} \mathrm{~mol}^{-1}\right): \mathrm{C}, 59.41 ; \mathrm{H}, 6.86 ; \mathrm{N}, 5.77$. Found: $\mathrm{C}, 59.22 ; \mathrm{H}, 6.84 ; \mathrm{N}, 5.75$. NMR data are given according to the numbering scheme used for L1 (vide supra). ${ }^{1} \mathrm{H}$ NMR $\left(266 \mathrm{~K}\right.$, toluene- $\left.d_{8}\right) \delta: 8.31\left(\mathrm{~d},{ }^{3} \mathrm{~J}_{\mathrm{HH}}=8.1 \mathrm{~Hz}, \mathrm{a}\right), 8.29(\mathrm{~d}$, $\left.{ }^{3} J_{\mathrm{HH}}=7.5 \mathrm{~Hz}, \mathrm{a}\right), 8.18\left(\mathrm{~d},{ }^{3} J_{\mathrm{HH}}=7.9 \mathrm{~Hz}, \mathrm{a}\right), 8.13\left(\mathrm{~d},{ }^{3} J_{\mathrm{HH}}=8.0 \mathrm{~Hz}, \mathrm{a}\right)$, $7.48\left(\mathrm{~d},{ }^{3} J_{\mathrm{HH}}=7.7 \mathrm{~Hz}, \mathrm{~d}\right), 7.48\left(\mathrm{~d},{ }^{3} J_{\mathrm{HH}}=7.7 \mathrm{~Hz}, \mathrm{~d}\right), 7.48$ (d, $\left.{ }^{3} J_{\mathrm{HH}}=7.7 \mathrm{~Hz}, d\right), 7.48\left(\mathrm{~d},{ }^{3} J_{\mathrm{HH}}=7.7 \mathrm{~Hz}, d\right), 7.28-6.96(\mathrm{~m}, \mathrm{~b}, \mathrm{c})$, 5.62-5.47 (m, 1'), $5.36\left(m, 1^{\prime}\right), 5.22\left(m, 1^{\prime}\right), 3.89\left(d,{ }^{3} J_{H H}=9.1 \mathrm{~Hz}\right.$, $\left.6^{\prime}\right), 3.78\left(\mathrm{~d},{ }^{3} J_{\mathrm{HH}}=6.9 \mathrm{~Hz}, 6^{\prime}\right), 3.44\left(\mathrm{t},{ }^{3} J_{\mathrm{HP}}=6.3 \mathrm{~Hz}, \mathrm{NMe}\right), 3.42(\mathrm{~d}$, $\left.{ }^{3} J_{\mathrm{HP}}=6.1 \mathrm{~Hz}, \mathrm{NMe}\right), 3.40\left(\mathrm{t},{ }^{3} J_{\mathrm{HP}}=5.2 \mathrm{~Hz}, \mathrm{NMe}\right), 3.39\left(\mathrm{t},{ }^{3} J_{\mathrm{HP}}=4.6\right.$ $\mathrm{Hz}, \mathrm{NMe}), 3.34\left(\mathrm{~d},{ }^{3} J_{\mathrm{HP}}=4.4 \mathrm{~Hz}, \mathrm{NMe}^{\prime}\right), 3.33\left(\mathrm{~d},{ }^{3} J_{\mathrm{HP}}=5.9 \mathrm{~Hz}\right.$, $\left.\mathrm{NMe}^{\prime}\right), 3.31\left(\mathrm{~d},{ }^{3} J_{\mathrm{HP}}=5.5 \mathrm{~Hz}, \mathrm{NMe}\right), 3.23\left(\mathrm{~d},{ }^{3} J_{\mathrm{HP}}=6.0 \mathrm{~Hz}, \mathrm{NMe}^{\prime}\right)$, $2.89\left(\mathrm{~d},{ }^{3} J_{\mathrm{HH}}=6.7 \mathrm{~Hz}, 3\right), 2.82\left(\mathrm{~d},{ }^{3} J_{\mathrm{HH}}=11.8 \mathrm{~Hz}, 3\right), 2.76-2.60(\mathrm{~m}$, 7), 2.52-2.36 (m, 7), 1.65-0.70 (m, 2, 3', 4, 5', 6, 9), 1.79 (d, $\left.{ }^{3} J_{\mathrm{HH}}=6.3 \mathrm{~Hz}, 8^{\prime}\right), 1.67\left(\mathrm{~d},{ }^{3} J_{\mathrm{HH}}=6.1 \mathrm{~Hz}, 8^{\prime}\right), 1.20\left(\mathrm{~d},{ }^{3} J_{\mathrm{HH}}=6.7 \mathrm{~Hz}\right.$, $\left.8^{\prime}\right), 1.12\left(\mathrm{~d},{ }^{3} \mathrm{~J}_{\mathrm{HH}}=7.3 \mathrm{~Hz}, 8^{\prime}\right), 0.99\left(\mathrm{~d},{ }^{3} J_{\mathrm{HH}}=6.5 \mathrm{~Hz}, 8\right), 0.92(\mathrm{~d}$, $\left.{ }^{3} J_{\mathrm{HH}}=6.9 \mathrm{~Hz}, 8\right), 0.82\left(\mathrm{~d},{ }^{3} \mathrm{~J}_{\mathrm{HH}}=6.8 \mathrm{~Hz}, 8\right), 0.77\left(\mathrm{~d},{ }^{3} J_{\mathrm{HH}}=6.8 \mathrm{~Hz}, 8\right)$, $0.72(m, 4), 0.69(m, 4), 0.60(m, 4), 0.57(m, 4) .{ }^{13} C\left\{{ }^{1} H\right\} N M R$ $\left(266 \mathrm{~K}\right.$, toluene- $\left.d_{8}\right) \delta: 145.2(\mathrm{e} / \mathrm{f}), 144.7$ (e/f), 144.5 (e/f), 144.0 (e/f), 139.9 (f/e), 139.7 (f/e), 136.4 (f/e), 136.3 (f/e), 131.4 (b/c), 130.4 (a), 130.1 (a), 130.0 (b/c), 129.9 (a), 129.7 (a), 129.5 (b/c), 129.4 (b/c), 129.1 (b/c), 129.0 (b/c), 128.9 (d), 128.8 (d), 128.4 (d), 128.1 (b/c), 127.9 (d), 127.6 (b/c), 80.0 (1), 79.7 (1), 79.2 (1), 78.9 (1), 49.5 (d, $\left.{ }^{3} J_{\mathrm{CP}}=5.5 \mathrm{~Hz}, 2\right), 49.2(\mathrm{t}$, $\left.{ }^{3} J_{\mathrm{CP}}=2.8 \mathrm{~Hz}, 2\right), 49.1\left(\mathrm{~d},{ }^{3} J_{\mathrm{CP}}=3.0 \mathrm{~Hz}, 2\right), 48.7(\mathrm{bs}, 2), 45.8(6)$, 45.2 (6), 44.5 (3), 44.3 (3), 42.8 (NMe), 42.4 (NMe'), 42.3 (NMe), 41.8 (NMe'), 41.3 (NMe), 40.2 (NMe'), $39.8\left(\mathrm{t},{ }^{3} J_{\mathrm{CP}}=3.2\right.$ $\mathrm{Hz}, \mathrm{NMe}^{\prime}$ ) 39.7 (NMe), 34.6 (4), 34.40 (4), 34.37 (4), 34.1 (4), 32.1 (5), 32.03 (5), 31.95 (5), 31.6 (5), 25.7 (7), 25.6 (7), 25.5 (7), 25.4 (7), 22.6 (9), 22.5 (9), 21.9 (9), 21.68 (9), 21.66 (9), $21.3(8), 21.2(8), 16.9\left(8^{\prime}\right), 16.7\left(8^{\prime}\right), 16.6\left(8^{\prime}\right), 16.5\left(8^{\prime}\right) .{ }^{31} \mathrm{P}\left\{{ }^{1} \mathrm{H}\right\}$ NMR $\left(161 \mathrm{MHz}, 266 \mathrm{~K}\right.$, toluene- $\left.d_{8}\right), \delta: 119.7,117.3,116.8$, 116.1

Trans- $\mathrm{PdCl}_{\mathbf{2}}(\mathbf{L 2})_{2} \quad(\mathbf{2 b}, 746.5 \mathrm{mg}, 96 \%)$. Anal. calcd for $\mathrm{C}_{82} \mathrm{H}_{114} \mathrm{Cl}_{2} \mathrm{~N}_{4} \mathrm{O}_{10} \mathrm{P}_{2} \mathrm{Pd}\left(1555.10 \mathrm{~g} \mathrm{~mol}^{-1}\right): \mathrm{C}, 63.33 ; \mathrm{H}, 7.39 ; \mathrm{N}$, 3.60. Found: $C, 63.34 ; H, 7.38 ; N, 3.59$. NMR data are given according to the numbering scheme used for $\mathbf{L 2}$ (vide supra). ${ }^{1} \mathrm{H}$ NMR (338 K, $\left.\mathrm{C}_{6} \mathrm{D}_{6}\right), \delta: 7.84\left(\mathrm{~d},{ }^{3} \mathrm{~J}_{\mathrm{HH}}=7.6 \mathrm{~Hz}, 2 \mathrm{H}, \mathrm{a}, \mathrm{a}^{\prime}\right), 7.44(\mathrm{t}$, $\left.{ }^{3} J_{\mathrm{HH}}=7.6 \mathrm{~Hz}, 2 \mathrm{H}, \mathrm{b}, \mathrm{b}^{\prime}\right), 7.23\left(\mathrm{~d},{ }^{3} \mathrm{~J}_{\mathrm{HH}}=7.6 \mathrm{~Hz}, 2 \mathrm{H}, \mathrm{d}, \mathrm{d}^{\prime}\right), 7.13(\mathrm{t}$, $\left.{ }^{3} J_{\mathrm{HH}}=7.6 \mathrm{~Hz}, 2 \mathrm{H}, \mathrm{c}, \mathrm{c}^{\prime}\right), 4.97$ (bs, 3), $4.84(\mathrm{~m}, 1 \mathrm{H}, 12), 3.55$ $\left(\mathrm{t},{ }^{3} J_{\mathrm{HP}}=5.1 \mathrm{~Hz}, 6 \mathrm{H}, \mathrm{NMe}, \mathrm{NMe}^{\prime}\right), 3.46\left(\mathrm{~s}, 3 \mathrm{H}, \mathrm{OCH}_{3}\right), 2.49(\mathrm{~m}, 1 \mathrm{H}$, 23), $2.33(\mathrm{~m}, 1 \mathrm{H}, 23), 2.04(\mathrm{~m}, 22), 1.87-0.78(\mathrm{~m}, 30 \mathrm{H}), 1.71(\mathrm{~s}$, $\left.\mathrm{CH}_{3}(\mathrm{C}=\mathrm{O})\right), 1.52\left(\mathrm{~d}, 3^{3} \mathrm{HH}_{\mathrm{H}}=6.5 \mathrm{~Hz}, 21\right), 0.83(\mathrm{~s}, 18), 0.73(\mathrm{~s}, 3 \mathrm{H}$, 19). ${ }^{13} \mathrm{C}\left\{{ }^{1} \mathrm{H}\right\}$ NMR (338 K, $\left.\mathrm{C}_{6} \mathrm{D}_{6}\right), \delta: 174.0$ (24), $170.0(\mathrm{C}=\mathrm{O})$, 145.2 (e/f), 131.6 (c), 130.5 (d), 128.6 (b), 125.9 (a), 80.3 (d, $\left.{ }^{2} J_{\mathrm{CP}}=7.9 \mathrm{~Hz}, 12\right), 74.2(3), 51.0\left(\mathrm{OCH}_{3}\right), 47.3(14), 47.0(17), 42.5$ (5), $41.5\left(\mathrm{t}^{2}{ }^{2} \mathrm{CP}_{\mathrm{CP}}=5.7 \mathrm{~Hz}, \mathrm{NMe}, \mathrm{NMe}^{\prime}\right), 38.9$ (20), 35.4 (8/9), 34.4 (8/9), 33.3 (1), 32.7 (23), 31.5 (22), 31.4, 28.5, 28.1, 27.12, 27.07, 24.8, 24.7, 23.3 (18), $21.0\left(\mathrm{CH}_{3}(\mathrm{C}=\mathrm{O})\right), 18.8$ (21), 13.1 (19). ${ }^{31} \mathrm{P}\left\{{ }^{1} \mathrm{H}\right\}$ NMR $\left(338 \mathrm{~K}, \mathrm{C}_{6} \mathrm{D}_{6}\right), \delta: 113.5$.

DFT calculations. Molecular structure optimizations and frequencies calculations were performed with the Gaussian09 program (revision D.01) ${ }^{22}$ using the B3LYP method, ${ }^{23}$ including the D3 dispersion correction by Grimme with Becke Johnson damping. ${ }^{24}$ The def2-SVP ${ }^{25}$ basis (all atoms) and pseudo potential (palladium) were used and the "ultrafine" grid was employed in all calculations. All the structures were optimized in toluene ( $298 \mathrm{~K}, 1 \mathrm{~atm})$ using the PCM method. ${ }^{26}$ Stationary points were characterized by vibrational analysis. Atomic coordinates and views of calculated structures are given in ESI. Solid state structure determination and crystal data for $(\mathbf{M}, \mathbf{P})-\mathbf{1 a}$. Single crystals of trans- $(M, P)-[\mathrm{Pd}(\mu-\mathrm{Cl}) \mathrm{Cl}(\mathbf{L} \mathbf{1})]_{2}$ suitable for the $\mathrm{X}$-ray diffraction study were obtained by slow evaporation of a toluene solution of 1a. Intensities were collected using a Bruker SMART APEX-DUO diffractometer with graphite-monochromated Mo K $\alpha$ radiation $(\lambda=0.71073 \AA$ ) following standard procedures. Intensities were integrated and corrected for absorption effects using the SAINT+ ${ }^{27}$ and $\mathrm{SADABS}^{28}$ programs, included in the APEX2 package. The structure was solved by the Patterson's method. All nonhydrogen atoms were located in the subsequent Fourier maps. Refinement was carried out by full-matrix least-square procedure (based on $F_{0}{ }^{2}$ ) using anisotropic temperature factors for all non-hydrogen atoms. All $\mathrm{C}-\mathrm{H}$ hydrogen atoms were placed in calculated positions with fixed isotropic thermal parameters (1.2xU equiv of the parent carbon atom). Calculations were performed with SHELX- $97^{29}$ program implemented in the WinGX package. ${ }^{30}$

$\mathrm{C}_{48} \mathrm{H}_{66} \mathrm{Cl}_{4} \mathrm{~N}_{4} \mathrm{O}_{2} \mathrm{P}_{2} \mathrm{Pd}_{2} \cdot \mathrm{C}_{7} \mathrm{H}_{8}, M=1239.72 \mathrm{~g} \mathrm{~mol}^{-1}, T=100(2) \mathrm{K}$, triclinic, $\mathrm{P} 1, a=10.2297(7) \AA, b=10.7327(7) \AA, c=14.5425(10)$ $\AA, \alpha=82.1650(10)^{\circ}, b=74.8310(10)^{\circ}, v=66.0270(10)^{\circ}, V=$ 1407.28(16) $\mathrm{A}^{3}, Z=1,1.463 \mathrm{~g} \mathrm{~cm}^{-3}, \mu=0.929 \mathrm{~mm}^{-1}, \mathrm{~F}(000)$ 638 , orange prism, $0.320 \times 0.200 \times 0.070 \mathrm{~mm}, \theta$ range for data collection: 2.078 to $28.549^{\circ}$; limiting indexes: $-13 \leq h \leq 13,-13 \leq k \leq 13,-19 \leq 1 \leq 19$, reflections collected/unique: 21566/12500 $[\mathrm{R}(\mathrm{int})=0.0174]$, data/restraints/parameters: $12500 / 3 / 633, \operatorname{GOF}\left(F^{2}\right) 1.069, R_{1}=0.0328[/>2 \sigma(/)], 0.0366$ (all data), $w R_{2}=0.0653[l>2 \sigma(l)], 0.0681$ (all data), absolute structure parameter: $-0.007(12)$, largest diff. peak and hole: 0.720 and $-0.534 \mathrm{e} \cdot \mathrm{A}^{-3}, \mathrm{CCDC}$ deposit number 1587843 .

\section{Conflicts of interest}

There are no conflicts to declare. 


\section{Acknowledgements}

Financial support from the Ministerio de Economía y Competitividad (MINECO/FEDER) of Spain (Projects CTQ201342532-P and CTQ2016-75884-P), Diputación General de Aragón (DGA/FSE E07) and the University of Pisa is gratefully acknowledged. V.P. thanks the resources of the supercomputer "Memento" and the technical expertise and assistance provided by the Institute for Biocomputation and Physics of Complex Systems (BIFI), Universidad de Zaragoza. A.P. acknowledges financial support from the ERASMUS+ programme.

\section{Notes and references}

$\S$ For brevity, only the configuration of the biphenyl unit in L1, L2, and in the corresponding complexes will be specified, the configuration of the alkoxy substituents being invariant (see ESIFigure $\mathrm{S} 1$ for the assignation of the $M$ and $P$ descriptors).

$\S \S$ For the sake of comparison, cis- $(M, P)-\mathrm{PdCl}_{2}(\mathbf{L} \mathbf{1})_{2}$, i.e. the cis isomer of $\mathrm{Xa}$, was found to be less stable $\left(\Delta G=+10.9 \mathrm{kcal} \mathrm{mol}^{-1}\right)$, thus suggesting that, like for the dinuclear complexes $[\mathrm{PdCl}(\mu-$ Cl)(L1) $]_{2}$, also for the mononuclear species $\mathrm{PdCl}_{2}(\mathbf{L 1})_{2}$ the cis arrangement is clearly disfavoured with respect to the trans one, reasonably as a consequence of the high steric demand of $\mathbf{L} \mathbf{1}$.

1 P. J. Walsh, A. E. Lurain, J. Balsells, Chem. Rev. 2003, 103, 3297; (b) A. Alexakis, D. Polet, C. Benhaim, S. Rosset, Tetrahedron: Asymmetry 2004, 15, 2199; (c) A. Alexakis, C. Benhaim, S. Rosset, M. Humam, J. Am. Chem. Soc. 2002, 124, 5262; (d) A. Alexakis, D. Polet, S. Rosset, S. March, J. Org. Chem. 2004, 69, 5660; (e) K. Wakabayashi, K. Aikawa, S. Kawauchi, K. Mikami, J. Am. Chem. Soc. 2008, 130, 5012; (e) M. T. Reetz, T. Neugebeauer, Angew. Chem. Int. Ed. 1999, 38, 179; (f) W. Chen, J. Xiao, Tetrahedron Lett. 2001, 42, 2897; (g) W. Chen, J. Xiao, Tetrahedron Lett. 2001, 42, 8737; (f) A. Iuliano, D. Losi, S. Facchetti, J. Org. Chem. 2007, 72, 8472; (g) M. Dieguez, O. Pamies, A. Ruiz, S. Castillon, C. Claver, Chem. Eur. J. 2001, 7, 3086; (h) S. Wunnemann, R. Frohlich, D. Hoppe, Eur. J. Org. Chem. 2008, 684; (i) C. Monti, C. Gennari, U. Piarulli, Chem. Eur. J. 2007, 13, 1547; (j) L. Pisani, C. Bochicchio, S. Superchi, P. Scafato, Eur. J. Org. Chem. 2014, 5939.

2 (a) Aikawa, K. Mikami, Chem. Commun. 2012, 48, 11050; (b) K. Mikami, K. Aikawa, Y. Yusa, J. J. Jodry, M. Yamanaka, Synlett 2002, 1561.

3 A. Iuliano, Tetrahedron: Asymmetry 2010, 21, 1943.

4 V. R. Jumde, A. Iuliano, Adv. Synth. Catal. 2013, 355, 3475.

5 (a) L. Lunazzi, M. Mancinelli, A. Mazzanti, S. Lepri, R. Ruzziconi, M. Schlosser, Org. Biomol. Chem. 2012, 10, 1847; (b) J. Veciana, M. I. Crespo, Angew. Chem. Int. Ed. Engl. 1991, 30, 74; (c) F. Gasparrini, L. Lunazzi, S. Alcaro, C. Villani, J. Org. Chem. 1995, 60, 5515; (d) I. D'Acquarica, F. Gasparrini, M. Pierini, C. Villani, G. Zappia, J. Sep. Sci. 2006, 29, 1508; (e) F. Maier, O. Trapp, Angew. Chem. Int. Ed. 2012, 51, 2985; (f) F. Maier, O. Trapp, Chirality 2013, 25, 126; (g) P. U. Biedermann, V. Schurig, I. Agranat, Chirality 1997, 9, 350; (h) A. Mazzanti, L. Lunazzi, R. Ruzziconi, S. Spizzichino, M. Schlosser, Chem.Eur. J. 2010, 16, 9186; (i) G. Storch, F. Maier, P. Wessig, O. Trapp, Eur. J. Org. Chem. 2016, 5123.

6 (a) M. Yamanaka, K. Mikami, Organometallics 2002, 21, 5847; (b) M. Yamanaka, K. Mikami, Organometallics 2005, 24, 4579 .

7 (a) A. Iuliano, S. Facchetti, G. Uccello Barretta, J. Org. Chem. 2006, 71, 4943; (b) R. Zalubovskis, E. Fjellander, Z, Szabo, C.
Moberg, Eur. J. Org. Chem 2007, 1085; (c) V. R. Jumde, A. Iuliano, Eur. J. Org. Chem. 2013, 4294.

8 (a) A. Iuliano, S. Facchetti, T. Funaioli, Chem. Commun., 2009, 457; (b) S. Facchetti, I. Cavallini, F. Marchetti, A. Iuliano, Organometallics 2009, 28, 4150; (c) G. Iannucci, A. Iuliano, J. Organomet. Chem. 2016, 806, 88.

9 G. P. Petrova, H.-B. Li, K. Maruoka, K. Morokuma, J. Phys. Chem. B 2014, 118, 5154.

10 (a) I. Ayora, R. M. Ceder, M. Espinel, M. Rocamora, M. Serrano, Organometallics 2011, 30, 115; (b) J. M. Brunel, T. Constantieux, G. Buono, J. Org. Chem. 1999, 64, 8940; (c) R. Hilgraf, A. Pfaltz, Adv. Synth. Catal. 2005, 347, 61; (d) K. N. Gavrilov, S. V. Zhelgov, E. A. Rastorguev, N. N. Groshkin, M. G. Maksimova, E. B. Benetsky, V. A. Davankov, M. T. Reetz, Adv. Synth. Catal. 2010, 352, 2599; (e) M. J. Bravo, I. Favier, N. Saffon, R. M. Ceder, G. Muller, M. Gomez, M. Rocamora, Organometallics 2014, 33, 771; (f) K. N. Gavrilov, S. V. Zhelgov, M. N. Gavrilova, I. M. Novikov, M. G. Maksimova, N. N. Groshkin, E. A. Rastorguev, V. A. Davankov, Tetrahedron 2012, 68, 1581; (g) K. N. Gavrilov, V. N. Tsarev, A. A. Shiryaev, O. G. Bondarev, S. E. Lyubimov, E. B. Benetsky, A. A. Korlyukov, M. Y. Antipin, V. A. Davankov, H. J. Gais, Eur. J. Inorg. Chem. 2004, 629; (h) V. N. Tsarev, S. E. Lyubimov, O. G. Bondarev, A. A. Korlyukov, M. Y. Antipin, P. V. Petrovskii, V. A. Davankov, A. A. Shiryaev, E. B. Benetsky, P. A. Vologzhanin, K. N. Gavrilov, Eur. J. Org. Chem. 2005, 2097; (i) K. N. Gavrilov, E. B. Benetskiy, T. B. Grishina, E. A. Rastorguev, M. G. Maksimova, S. V. Zheglov, V. A. Davankov, B. Schäffner, A. Börner, S. Rosset, G. E. Bailat, A. Alexakis, Eur. J. Org. Chem. 2009, 3923.

11 Stereochemistry of Organic Compounds E. L. Eliel, S. H. Wilen, Wiley, 1994.

12 The line shape analyses have been carried out using the program DNMR3 (D. S. Stephenson, G. Binsch J. Magn. Reson. 1978, 30, 625) included in Spinworks 3.0 by the Chemistry NMR Lab, University of Manitoba Winnipeg, Manitoba Canada.

13 Selected references: (a) F. Bu, P. Mehlmann, C. MuckLichtenfeld, K. Bergander, F. Dielmann, J. Am. Chem. Soc. 2016, 138, 1840; (b) A. Skarzynska, A. Trzeciak, M. Siczek, Inorg. Chim. Acta 2011, 365, 204; (c) J. Li, M. Lutz, A. L. Spek, G. P. M. van Klink, G. van Koten, R. J. M. K. Gebbink, J. Organomet. Chem. 2010, 695, 2618; (d) C. J. Cobley, D. D. Ellis, A. G. Orpen, P. G. Pringle, J. Chem. Soc., Dalton Trans. 2000, 1101; (e) A. M. Z. Slawin, J. D. Woollins, Q. Zhang, Inorg. Chem. Commun. 1999, 2, 386.

14 (a) I. Alvarado-Beltran, M. L. Gonzalez, Y. Escudie, E. Maerten, N. Saffon-Merceron, I. Fabing, C. A. Toledano, A. Baceiredo, Tetrahedron 2016, 72, 1662; (b) A. Tohme, S. Labouille, T. Roisnel, V. Dorcet, D. Carmichael, F. Paul, Dalton Trans. 2014, 43, 7002; (c) T. M. Konrad, J. A. Fuentes, A. M. Z. Slawin, M. L. Clarke, Angew. Chem., Int. Ed. 2010, 49, 9197; (d) S. Vuoti, J. Autio, M. Laitila, M. Haukka, J. Pursiainen, Eur. J. Inorg. Chem. 2008, 397; (e) S. Vuoti, M. Haukka, J. Pursiainen, J. Organomet. Chem. 2007, 692, 5044; (f) P. Stepnicka, I. Cisarova, R. Gyepes, Eur. J. Inorg. Chem. 2006, 926; (g) M. B. Dinger, M. J. Scott, Inorg. Chem. 2001, 40, 856.

15 (a) C. Azerraf, S. Cohen, D. Gelman, Inorg. Chem. 2006, 45, 7010; (b) O. Grossman, C. Azerraf, D. Gelman, Organometallics 2006, 25, 375.

16 A. Bondi, J. Phys. Chem. 1964, 68, 441.

17 For a theoretical study on the factors governing the puckering of $\mathrm{M}_{2}(\mu-\mathrm{X})_{2}$ moiety see (a) G. Aullon, G. Ujaque, $\mathrm{A}$. Lledos, S. Alvarez, Chem. Eur. J. 1999, 5, 1391. (b) G. Aullon, G. Ujaque, A. Lledos, S. Alvarez, P. Alemany, Inorg. Chem. $1998,37,804$.

18 (a) A. B. Chaplin, J. A. Harrison, P. J. Dyson, Inorg. Chem. 2005, 44, 8407; (b) M. Witt, H. W. Roesky, Chem. Rev. 1994, 
94, 1163; (c) S. S. Krishnamurthy, Phosphorus, Sulfur, and Silicon Relat. Elem., 1994, 87, 101-111.

19 (a) T. A. Blake, S. S. Xantheas J. Phys. Chem. A 2006, 110, 10487; (b) E. D. Glendening, A. M. Halpern, J. Phys. Chem. A 2005, 109, 635.

20 J. R. Doyle, P. E. Slade, H. B. Jonassen, Inorg. Synth. 1960, 6, 216.

21 (a) A. Macchioni, G. Ciancaleoni, C. Zuccaccia, D. Zuccaccia, Chem. Soc. Rev. 2008, 37, 479; (b) Y. Cohen, L. Avram, L. Frish, Angew. Chem., Int. Ed. 2005, 44, 520; (c) P. S. Pregosin, P. G. A. Kumar, I. Fernandez, Chem. Rev. 2005, 105, 2977.

22 Gaussian 09, Revision D.01, M. J. Frisch, G. W. Trucks, H. B. Schlegel, G. E. Scuseria, M. A. Robb, J. R. Cheeseman, G. Scalmani, V. Barone, B. Mennucci, G. A. Petersson, H Nakatsuji, M. Caricato, X. Li, H. P. Hratchian, A. F. Izmaylov, J. Bloino, G. Zheng, J. L. Sonnenberg, M. Hada, M. Ehara, K. Toyota, R. Fukuda, J. Hasegawa, M. Ishida, T. Nakajima, Y. Honda, O. Kitao, H. Nakai, T. Vreven, J. A. Montgomery, Jr., J. E. Peralta, F. Ogliaro, M. Bearpark, J. J. Heyd, E. Brothers, K. N. Kudin, V. N. Staroverov, R. Kobayashi, J. Normand, K. Raghavachari, A. Rendell, J. C. Burant, S. S. Iyengar, J. Tomasi, M. Cossi, N. Rega, M. J. Millam, M. Klene, J. E. Knox, J. B. Cross, V. Bakken, C. Adamo, J. Jaramillo, R. Gomperts, R. E. Stratmann, O. Yazyev, A. J. Austin, R. Cammi, C. Pomelli, J. W. Ochterski, R. L. Martin, K. Morokuma, V. G. Zakrzewski, G. A. Voth, P. Salvador, J. J. Dannenberg, S. Dapprich, A. D. Daniels, Ö. Farkas, J. B. Foresman, J. V. Ortiz, J. Cioslowski, D. J. Fox, Gaussian, Inc., Wallingford CT, 2009.

23 (a) C. Lee, W. Yang, R. G. Parr, Phys. Rev. B 1988, 37, 785; (b) A. D. Becke, J. Chem. Phys. 1993, 98, 1372; (c) A. D. Becke, J. Chem. Phys. 1993, 98, 5648.

24 S. Grimme, S. Ehrlich, L. Goerigk, J. Comp. Chem. 2011, 32, 1456.

25 F. Weigend, R. Ahlrichs, Phys. Chem. Chem. Phys. 2005, 7, 3297.

26 J. Tomasi, B. Mennucci, R. Cammi, Chem. Rev. 2005, 105, 2999.

27 SAINT+, version 6.01; Bruker AXS, Inc.; Madison, WI, 2001.

28 G. M. Sheldrick, SABADS, University of Göttingen: Göttingen, Germany, 1999.

29 (a) G. M. Sheldrick, SHELXL-97, University of Göttingen: Göttingen, Germany, 1997; (b) G. M. Sheldrick, Acta Crystallogr., 2008, A64, 112.

30 L. J. Farrugia, J. Appl. Crystallogr., 1999, 32, 837. 